\title{
A IMPORTÂNCIA DAS CERTIFICAÇÕES AMBIENTAIS PARA O COMÉRCIO INTERNACIONAL: UM DIFERENCIAL DE COMPETITIVIDADE PARA AS EMPRESAS EXPORTADORAS
}

\author{
Cynthia Veras Godeiro \\ Graduada em Tecnologia em Comércio Exterior, pelo Instituto Federal de Educação, \\ Ciência e Tecnologia do Rio Grande do Norte.E-mail: cynthia_veras@ hotmail.com \\ Erika Araújo da Cunha Pegado \\ Graduada em Licenciatura em História pela Universidade Federal do Rio Grande do Norte \\ (1990), graduação em Bacharelado em Direito pela Universidade Federal do Rio Grande \\ do Norte (1997) e mestrado em Engenharia de Produção pela Universidade Federal do Rio \\ Grande do Norte (2004). Professora do IFRN.
}

Email: erika@cefetrn.br

\section{RESUMO}

A temática do desenvolvimento sustentável relacionada, principalmente, à gestão ambiental nas organizações influencia na postura das empresas que buscam se adequar às normas ambientais para que possam competir no mercado. A certificação ambiental, além de facilitar um intercâmbio comercial entre as empresas exportadoras, promove benefícios para a organização, no que diz respeito nos aspectos da produtividade e vantagem competitiva. Esse trabalho se justifica pela a importância de estudos sobre a dinâmica das relações comerciais entre os países, tendo em vista que o assunto meio ambiente atrelado ao comércio internacional é destaque no cenário atual. Aplicou-se metodologia da pesquisa exploratória descritiva em documentos oficiais, livros, artigos científicos. Verificou-se o impacto que as certificações ambientais causam no intercâmbio comercial entre os Estados e o desempenho das empresas ambientalmente corretas no mercado internacional. Por fim, são apresentados motivos para que uma empresa adote um Sistema de Gestão Ambiental, entre os quais redução de custos em função da economia de recursos naturais e diminuição da geração de resíduos, conquista de mercados restritos, economia de recursos pertinentes a processos judiciais, facilidade para obtenção de financiamentos junto a organismos multilaterais de crédito, criação de uma "imagem verde", ganho de status e confiabilidade no mercado internacional.

PALAVRAS-CHAVE: Comércio Internacional, Certificação ambiental, Competitividade.

\begin{abstract}
The thematic of sustainable development related mainly to the environmental management in organizations influences the attitude of companies seeking to adapt to the environmental standards to compete in the market. The environmental certification facilitates trade between the exporting companies and is also beneficial to the organization regarding the aspects of productivity and competitive advantage. This work is justified by the importance of studies on the dynamics of trade relations between countries in order that the environmental issue linked to international trade is highlighted in the current scenario. It
\end{abstract}


applied descriptive exploratory research methodology to official documents, books, scientific articles. The impact that environmental certifications have on trade between the States and the environmentally sound business performance in international markets has been considered. Finally, we present reasons why a company should adopt an Environmental Management System, including cost reduction as a way of saving natural resources and reduction of waste generation, acquisition of restricted markets, economy of resources relevant to legal proceedings, ease of obtaining financing from multilateral lending agencies, creating a "green image", gain status and reliability in the international market.

KEY-WORDS: International Trade, Environmental Certification, Competitiveness. 


\section{A IMPORTÂNCIA DAS CERTIFICAÇÕES AMBIENTAIS PARA O COMÉRCIO INTERNACIONAL: UM DIFERENCIAL DE COMPETITIVIDADE PARA AS EMPRESAS EXPORTADORAS}

\section{INTRODUÇÃO}

A temática do desenvolvimento sustentável ligada, principalmente, a gestão ambiental nas organizações têm sido bastante discutida e abordada nos dias atuais. Então a preocupação com o meio ambiente e a forma de como está sendo explorado tornou-se fundamental para a qualidade de vida no planeta, passando a ser um pré-requisito para o desenvolvimento social e democrático de uma nação. Conceituando o desenvolvimento sustentável de acordo com a Comissão Mundial sobre Meio Ambiente e Desenvolvimento, criada pelas Nações Unidas, temos: "Desenvolvimento capaz de suprir as necessidades da geração atual, sem comprometer a capacidade de atender as necessidades das futuras gerações. É o desenvolvimento que não esgota os recursos para o futuro."

Esta definição nos leva a refletir sobre a forma de exploração das atividades econômicas no meio-ambiente e de como as empresas devem estar comprometidas com as questões ambientais para que possamos preservar os recursos para as próximas gerações. Nesta perspectiva, um número crescente de consumidores passou a se preocupar com a degradação ambiental, procurando consumir em todo seu ciclo de vida bens que sejam ambientalmente corretos. Isto influencia diretamente na postura das empresas que procuram se adequar às normas ambientais para que possam competir no mercado.

No âmbito do comércio internacional, as certificações ambientais possuem uma grande importância, na medida em que essas certificações são exigências de vários mercados, tais como: Europa e Estados Unidos. As certificações ambientais podem ter dois objetivos no comércio internacional: barreira comercial não tarifária ou defesa comercial e proteção contra dumping ecológico, temas que pretendem ser discutidos no decorrer da pesquisa.

A certificação ambiental, além de facilitar um intercâmbio comercial entre as empresas exportadoras, promove benefícios no âmbito sócio-econômico e ambiental da organização, no que diz respeito estrutura interna. Possibilitando-a evoluir para uma posição de maior produtividade e maior vantagem competitiva.

Diante do exposto nesta fase introdutória, podemos inferir que a temática abordada neste trabalho se justifica pela sua importância e polêmica para a dinâmica das relações comerciais entre os países, tendo em vista que o assunto meio ambiente atrelado ao comércio internacional está ganhando demasiado destaque no cenário atual, como já foi dito.

Nesta perspectiva, a pesquisa consiste em uma relevante contribuição no setor acadêmico, pois pretende identificar as relações que envolvem o meio ambiente e o comércio internacional. No que tange à sociedade, será a oportunidade de conscientizar ambientalmente as empresas e ajudá-las a se tornarem mais competitivas no comércio exterior. Tendo em vista, que as práticas ambientais por parte das empresas têm sido um entrave nas relações de troca entre países, principalmente naqueles países desenvolvidos em relação aos países em desenvolvimento, esse estudo faz-se necessário. 
A metodologia aplicada neste trabalho incide na busca e pesquisa exploratória descritiva por meio de consultas a documentos oficiais, livros, artigos científicos. Também foi realizado um levantamento de dados secundários utilizando websites, por exemplo.

Conforme Gil (2002), a pesquisa bibliográfica é desenvolvida com base em materiais prontos, constituídos principalmente de livros, artigos científicos e periódicos, podendo a pesquisa de um trabalho ser exclusivamente por meio de fontes bibliográficas. Portanto, a pesquisa bibliográfica constitui a base teórica de sustentabilidade e credibilidade quando da interpretação dos dados levantados.

A seleção de artigos científicos na Internet consiste em uma das fontes para a busca de artigos mais atualizados no momento da confecção desse trabalho, sendo, portanto de relevância importância para a atualização das informações. Também será realizada a leitura de algumas monografias pertinente ao assunto escolhido.

Para a pesquisadora, tanto da comunidade acadêmica quanto da comunidade em geral, a escolha do tema, se justifica pela importância de discutir os benefícios e vantagens que uma empresa exportadora possui ao adotar um Sistema de Gestão Ambiental e com isso, adquirir uma certificação ambiental, tornando-se mais competitiva no comércio internacional. Com isso, a análise desses aspectos é relevante para uma suposta conscientização do setor empresarial quanto à importância de se adotar uma política ambiental em sua empresa.

Diante da discussão, dos fatores intervenientes abordados e das justificativas relevantes a cerca do tema proposto nesta pesquisa, surge um lugar para a seguinte problemática de pesquisa: De que forma a certificação ambiental em uma empresa proporciona um diferencial de competitividade no comércio internacional?

De acordo com esta problemática, temos como objetivo geral desta pesquisa: verificar o impacto que as certificações ambientais causam no intercâmbio comercial entre os Estados e como as empresas ambientalmente corretas competem no mercado internacional. Já no que diz respeito aos objetivos específicos, temos: a) Conhecer os principais processos de certificação ambiental e sua importância para intercâmbio comercial entre os países; b) Discutir a utilização da certificação ambiental como barreira comercial não tarifária ou defesa do meio-ambiente; c) Identificar os benefícios - econômicos, sociais e ambientais que uma certificação ambiental proporciona para uma empresa exportadora; d) Discutir como as empresas se tornam mais competitivas no mercado internacional após a certificação ambiental.

O trabalho encontra-se estruturado nas seguintes partes: o primeiro capítulo discute sobre a interação que existe entre o meio ambiente e o comércio internacional ao longo dos anos até a atualidade. Para tanto, faz-se um panorama dos princípios que norteiam a ciência do direito ambiental e a previsão normativa de assuntos relacionados ao meio ambiente no nosso ordenamento jurídico pátrio, e ainda mais especificamente na Constituição Federal. Ainda nesta primeira ideia, faz-se uma breve exposição histórica do comércio internacional sob o enfoque dos acontecimentos relevantes para o mundo ambiental. 
No segundo capítulo, adentramos na questão das certificações ambientais em meio ao comércio internacional, ou seja, como estas possuem um poder impactante nas relações e trocas cambiais entre os países. Para tanto, temos a elucidação das normas internacionais de certificação tidas como parâmetro para a matéria ambiental, no caso normas da Série ISO 14.000, e seu respectivo respaldo positivo dentro de uma organização.

O terceiro capítulo trata dos tópicos diretamente relacionados à problemática desta pesquisa, de maneira que discute sobre a importância que a certificação ambiental possui dentro de uma empresa que pretende tornar-se mais competitiva no comércio internacional. Para isso, são abordadas as melhorias na prática de gestão e conscientização do corpo interno de uma empresa que se propõe a exportar e possuir um diferencial no mercado global.

Por fim, nas considerações finais verifica-se a maneira pela qual a empresa que participa do comércio internacional pode obter um diferencial a mais no mercado competitivo, adotando uma postura ambientalmente correta capaz de gerar uma certificação neste quesito.

\section{MEIO AMBIENTE E COMÉRCIO INTERNACIONAL}

Por séculos o ser humano habita o planeta terra e apenas recentemente começou a se preocupar de forma sistematizada com os malefícios que estavam fazendo ao meio ambiente. Apesar de toda a sua evolução, seja enquanto sociedade organizada ou tecnologicamente, continuou comportando-se de forma indiferente em relação ao uso dos recursos naturais, demonstrando sua visão fundamentalmente antropocêntrica.

Com isso, cultua-se no pensamento ocidental que os recursos naturais são infinitos e que estes estariam disponíveis para que o homem usasse e abusasse das suas riquezas naturais. Esta cultura baseada no antropocentrismo, fez com que ocorressem diversos rituais em nome de divindades que causaram verdadeiras catástrofes naturais.

Antes de adentrarmos na correlação temática que se pretende abordar neste trabalho entre a esfera ambiental e o comércio exterior, precisamos definir o conceito de meio ambiente. Conforme a lei $\mathrm{n}^{\mathrm{o}}$ 6.938/81 que dispõe sobre a Política Nacional do Meio Ambiente, afirma: "meio ambiente, o conjunto de condições, leis, influências e interações de ordem física, química e biológica que permite, abriga e rege a vida em todas as suas formas". A partir desta definição, podemos inferir que é um texto bem amplo e que engloba não só a interação do homem com o meio ambiente, como também as outras formas de manifestação da vida.

Contudo, a legislação estadual do Estado do Rio Grande do Norte, através da lei complementar $n^{\circ} 272$, de 3 de março de 2004, já engloba conceitos mais atualizados, disposto no art. $5^{\mathrm{o}}$ da seguinte maneira: "Para os fins previstos nesta Lei Complementar, entende-se por: I - meio ambiente: o conjunto de condições, leis, influências e interações de ordem física, química e biológica, bem como os fatores sócio-econômicos e culturais, incluindo o ambiente construído, que permite, abriga e rege a vida em todas as suas formas;" 
Sendo assim, o direito ao meio ambiente destaca-se como uma parte do direito difuso, na medida em que é um interesse de toda a comunidade zelar e proteger o meio ambiente, levantando a impossibilidade de descobrir quem são os titulares desse interesse.

Tendo em vista que o meio ambiente é um bem a ser tutelado por todos, a partir da década de 60 do séc. XX vários estudiosos e cientistas publicaram estudos sobre as ameaças que a sociedade industrializada provocava em nosso mundo. Com isso, essa preocupação com meio ambiente adveio principalmente após as destruições provocadas pela Segunda Guerra Mundial e os efeitos catastróficos causados pelas bombas atômicas de Hiroshima e Nagasaki no Japão.

Ainda nesta década de 60 , houve a criação do Clube de Roma, que visava à discussão da crescente crise ambiental por especialistas da área e com objetivo de encontrar soluções para o problema. O clube de Roma, em 1972, publicou o relatório "The Limits of Growth" que significa os "limites do crescimento", tendo este documento o objetivo de alertar as autoridades sobre o efeito destruidor do modelo de desenvolvimento vigente.

Nesta perspectiva histórica do pensamento ecológico no mundo, a Organização das Nações Unidas convocou a Conferência de Estocolmo, em 1972, na Suécia, criou a Comissão de Brutdland em 1987 - divulgando o documento "Nosso futuro comum", que traz a tese do desenvolvimento sustentável e posteriormente a Conferência do Rio, em 1992. Ambas com grandes repercussões sobre a conscientização das questões ambientes levadas a todo o mundo. Com relação a esta última Conferência, realizada no Brasil, Bianchi (2008, p. 33) infere:

Foi a partir da ECO-92 que as políticas sobre comércio e meio ambiente começaram a ser fortemente discutidas, levando-se em consideração as respectivas implicações sobre as possibilidades de um desenvolvimento sustentável. Essa Conferência internacional realizada em 1992 produziu um documento denominado Agenda 21, que objetiva a preparação do mundo tendose em vista os desafios futuros, além do propósito de se obter um consenso mundial, assim como um comprometimento político num nível mais elevado no que concerne ao desenvolvimento e à cooperação na área do meio ambiente.

Ainda nesta época, a sociedade vivenciou a crise do petróleo, a derrocada do comunismo, o início da revolução técnico-científica e o crescente aumento das transações comerciais entre os países. Essas transações comerciais no exterior são provenientes de uma acelerada internacionalização do capital que provocou um crescimento na globalização e consequentemente nas relações comerciais entre os países.

Portanto, com o constante crescimento e consolidação do comércio internacional, os cidadãos começam a se conscientizar dos problemas ambientais e a exigir que os governos e as empresas dos países desenvolvidos tomem algumas medidas estratégicas para diminuir o impacto do desenvolvimento econômico no meio ambiente. A diminuição dos poluentes e a adoção de um sistema de produção que levasse em consideração a questão ambiental foram amplamente defendidas pela sociedade ecologicamente consciente. No comércio exterior, os produtos importados e exportados pelos países também deveriam estar em conformidade com o princípio do desenvolvimento sustentável. 
Nesta perspectiva, a ciência que estuda as normas ambientais vem ganhando bastante destaque nesse cenário, de maneira a defender princípios que influenciam na correlação entre o homem, o comércio e o meio ambiente.

\title{
PRINCÍPIOS GERAIS DO DIREITO AMBIENTAL
}

Neste tópico abordam-se os princípios gerais que norteiam a ciência do Direito Ambiental. Sendo assim, temos que os princípios são tidos, neste aspecto, como a base ou fundamento do direito ao meio ambiente. Gomes Canotilho (2003, p. 166-167) discorre com muita propriedade sobre este assunto:

\begin{abstract}
Os princípios são normas jurídicas impositivas de uma optimização, compatíveis com vários graus de concretização, consoante os condicionalismos fáticos e jurídicos. Permitem o balanceamento de valores e interesses (não obedecem, como as regras, à 'lógica do tudo ou nada'), consoante o seu peso e ponderação de outros princípios eventualmente conflitantes.
\end{abstract}

A partir desta afirmação de Canotilho, ressalta-se a importância dos princípios na formação basilar de um ordenamento jurídico, conferindo a este um grau de legitimidade e eficácia perante a sociedade. Isto significa que para que haja uma aplicação justa do direito deve-se conhecer profundamente os princípios, na medida em que as leis são passíveis de mudanças de acordo com a dinâmica social.

Para tanto, surge alguns princípios, respaldados em declarações internacionais, que são os responsáveis pelo processo de formação e implementação do Direito Ambiental. São estes: Princípio do direito à sadia qualidade de vida; Princípio do acesso equitativo aos recursos naturais; Princípios usuário-pagador e poluidor-pagador; Princípio da precaução; Princípio da prevenção; Princípio da reparação; Princípio da informação; Princípio da participação e Princípio da obrigatoriedade da intervenção do Poder Público.

Basicamente, o princípio do direito à sadia qualidade de vida consiste em que o ser humano não deve procurar apenas viver e conservar a vida, e sim alcançar a tão sonhada "qualidade de vida". Sobre este assunto, a Conferência das Nações Unidas sobre Meio Ambiente, e em diversos lugares do mundo, tais como Estocolmo/72, Rio de Janeiro/ 92 e Estrasburgo/ 97 afirmaram generalizadamente que todo ser humano tem o direito a uma vida saudável e a um ambiente sadio. No que diz respeito a esse direito que goza o ser humano, Machado (2005, p. 54) diz:

\footnotetext{
A saúde dos seres humanos não existe somente numa contraposição a não ter doenças diagnosticadas no presente. Leva-se em conta o estado dos elementos da Natureza - águas, solo, ar, flora, fauna e paisagem - para se aquilatar se esses elementos estão em estado de sanidade e de seu uso advenham saúde ou doenças e incômodos para os seres humanos.
}

Esse preceito teve um reflexo considerável nas Constituições dos países pelo mundo, na medida em que o ordenamento interno destes passou a incorporar normas que asseguram o direito a um ambiente sadio para seu povo. Esta ideia presente na citação do autor supramencionado nos faz lembrar a conceituação feita sobre o desenvolvimento 
sustentável, em que devemos utilizar os recursos do meio de forma a não esgotá-lo para as futuras gerações.

Já o princípio de acesso equitativo aos recursos naturais assegura que todos devem desfrutar de forma igualitária dos bens que integram o meio ambiente para satisfazer as suas necessidades. Ou seja, o meio ambiente deve ser um bem de uso comum do povo. Neste sentido, dizemos que o acesso aos bens do meio ambiente pode ser: pelo consumo do bem (utilização dos recursos hídricos, a caça e pesca), o acesso causando poluição (lançamento de poluentes no ar ou água ou solo), e acesso para a contemplação da paisagem. Porém, devemos colocar que essa utilização dos meios deve ser feita de uma forma que não esgote os recursos para as gerações futuras. Sobre a função que o direito ambiental exerce na sociedade e toda essa problemática que envolve a utilização dos recursos naturais pelo homem, Machado (2005, p. 56):

O Direito Ambiental tem a tarefa de estabelecer normas que indiquem como verificar as necessidades de uso dos recursos ambientais. Não basta a vontade de usar esses bens ou a possibilidade tecnológica de explorá-los. É preciso estabelecer a razoabilidade dessa utilização, devendo-se, quando a utilização não seja razoável ou necessária, negar o uso, mesmo que os bens não sejam atualmente escassos.

Os princípios usuário-pagador e poluidor-pagador significa basicamente que a utilização dos recursos naturais pode ser gratuita ou paga. Ou seja, consiste em responsabilizar um poluidor pelos seus atos nocivos ao meio ambiente, evitando que a sociedade arque com os custos necessários para a recuperação deste. Essa possibilidade de cobrança pela utilização dos recursos do meio é proveniente da raridade desses recursos para a prevenção de catástrofes na natureza. Desta forma, podemos perceber no princípio do poluidor-pagador duas vertentes de alcance: a primeira de caráter preventivo que tem por objetivo evitar as ações que possam causar danos ao meio ambiente e a segunda é o caráter repressivo que uma vez ocorrido o dano, prevê a sua reparação proporcional a lesão causada à natureza. A respeito deste princípio e seu caráter duplo (preventivo e repressivo), Fiorillo (2005, p. 30) coloca:

\footnotetext{
Desse modo, num primeiro momento, impõe ao poluidor o dever de arcar com as despesas de prevenção dos danos ao meio ambiente que a sua atividade possa ocasionar. Cabe a ele o ônus de utilizar instrumentos necessários à prevenção dos danos. Numa segunda órbita de alcance, esclarece este princípio que, ocorrendo danos ao meio ambiente em razão da atividade desenvolvida, o poluidor será responsável pela sua reparação.
}

É importante destacar ainda sobre este assunto que o art. $225 \S 3^{\circ}$ da Constituição Federal prevê, com ineditismo, a responsabilidade penal para a pessoa jurídica que causar dano ao meio ambiente. "O princípio do poluidor-pagador determina a incidência e aplicação de alguns aspectos do regime jurídico da responsabilidade civil aos danos ambientais: a) responsabilidade civil objetiva; b) prioridade da reparação ao dano ambiental; e c) solidariedade para suportar os danos causados ao meio ambiente" (FIORILLO,2005 pag. $31)$.

O princípio da precaução consiste na ideia de prevenção do meio ambiente, ou seja, evitar o máximo possível a degradação deste. Para isso, criaram-se mecanismos jurídicos 
para precaver os possíveis danos ao meio ambiente e com isso protegê-los da ação devastadora do homem. O princípio da precaução não deve se confundir com o da Previsão que consiste na prevenção de um perigo iminente de danificar o meio ambiente, visando evitar o surgimento deste. A precaução aplica-se nos casos em que se tenha dúvida sobre a periculosidade de certa ação ou atividade para a natureza, decidindo-se a favor sempre do meio ambiente. Completando o que já foi dito, Machado (2005, p. 54) coloca:

\begin{abstract}
A implementação do princípio da precaução não tem por finalidade de imobilizar as atividades humanas. Não se trata da precaução que tudo impede ou que em tudo vê catástrofes ou males. O princípio da precaução visa à durabilidade da sadia qualidade de vida das gerações humanas e à continuidade da natureza existente no planeta.
\end{abstract}

O princípio da prevenção é aquele dever jurídico de evitar o esgotamento dos recursos naturais e este assunto vem sendo debatido em convenções, declarações e sentenças de tribunais internacionais. Por isso, caracterizasse como um dos princípios mais relevantes do Direito ambiental, bem como tem ganhado muita expressividade no plano internacional. Conforme o princípio 15 da Declaração do Rio de Janeiro sobre Meio Ambiente e Desenvolvimento (1992):

Para proteger o meio ambiente medidas de precaução devem ser largamente aplicadas pelos Estados segundo suas capacidades. Em caso de risco de danos graves ou irreversíveis, a ausência de certeza científica absoluta não deve servir de pretexto para procrastinar a adoção de medidas efetivas visando a prevenir a degradação do meio ambiente.

Este princípio da prevenção deve vir atrelado à formação de uma consciência ecológica na sociedade, através da implantação de uma política ambiental. Para tanto, surge a figura imprescindível do Estado que contribui com a prevenção de danos ambientais quando estipula punições para o poluidor, como também procura beneficiar, por meio de incentivos fiscais, aqueles que possuem uma postura harmônica com o meio ambiente.

O princípio da reparação determina que os governos possuam o dever de prever uma responsabilidade e indenização às vítimas por danos ambientais. Para tanto, procura-se reparar os danos causados ao meio ambiente através de medidas que possibilitem o contrabalanceamento de tal dano com ações positivas de preservação e conservação. Sobre este assunto, a Declaração do Rio de Janeiro (1992) em seu princípio 13 diz:

Os Estados deverão desenvolver legislação nacional relativa à responsabilidade e à indenização das vítimas da poluição e outros danos ambientais. Os Estados deverão cooperar, da mesma forma, de maneira rápida e mais decidida, na elaboração das novas normas internacionais sobre responsabilidade e indenização por efeitos adversos advindos dos danos ambientais causados por atividades realizadas dentro de sua jurisdição ou sob seu controle, em zonas situadas fora de sua jurisdição.

Em nosso ordenamento jurídico interno, as disposições sobre responsabilidade objetiva ambiental estão dispostas na Lei de Política Nacional do Meio ambiente (Lei 6.938/81) e com previsibilidade na Constituição Federal que considera imprescindível a reparação dos danos causados ao meio ambiente. 
O princípio da informação já assegura que todos devem ter acesso à informação que dispuser as autoridades públicas, bem como informações que envolvem riscos provenientes do meio ambiente. Sobre esse direito de informação que dispõe o cidadão, o autor Silva (2005) divide o princípio em três partes: direito de informar (inciso IV do art. $5^{\circ}$ da CF: "É livre a manifestação do pensamento, sendo vedado o anonimato".); direito de se informar (inciso XIV do art. $5^{\circ}$ da CF: "É assegurado a todos o acesso à informação e resguardado o sigilo da fonte, quando necessário ao exercício profissional") e direito de ser informado (inciso XXXIII do art. $5^{\circ}$ da CF: "Todos têm direito a receber dos órgãos públicos informações de seu interesse particular, ou de interesse coletivo ou geral, que serão prestadas no prazo da lei, sob pena de responsabilidade, ressalvadas aquelas cujo sigilo seja imprescindível à segurança da sociedade e do Estado").

O princípio da participação é aquele que permite a sociedade opinar e conhecer as decisões provenientes de órgãos sobre o meio ambiente. Esse princípio também engloba o dever de participação da coletividade nos assuntos que envolvem o meio ambiente, na qual aparecesse como titular desse direito. A respeito da participação de várias espécies de organizações interessadas na defesa e preservação do meio ambiente, destacamos o papel das ONG's que atuam fortemente na justiça para pleitear esse direito de ter um meio ambiente sadio. Fiorillo (2005, p. 41) diz:

\begin{abstract}
Com isso, observa-se, comumente, em ações civis públicas, determinada ONG, ingressando como autora, sustentar caber à pessoa jurídica de direito público o dever de tutelar o meio ambiente. O ente público, por sua vez, ao responder à demanda, propõe reconvenção, alegando, corretamente, que o dever de tutela do meio ambiente cabe não apenas a ele, mas também àquela $\mathrm{ONG}$, na medida em que esta recebe dotação orçamentária e há precisão constitucional do art. 225, caput, que estrutura toda a sociedade na defesa do meio ambiente, de que todos (pessoas físicas e jurídicas) obrigam-se a tutelá-lo. Atente-se que não se trata de um aconselhamento, mas sim de um dever da coletividade.
\end{abstract}

Por fim, nós temos o princípio da obrigatoriedade da intervenção do Poder Público que consiste na intervenção compulsória do Estado nas questões relacionadas ao meio ambiente, a fim de que possa proporcionar uma melhor qualidade ao meio ambiente. Com isso, "a administração pública não pode omitir-se de adotar as medidas que lhe competem, sob pena de responsabilidade civil por omissão, e criminal pelo crime de prevaricação." (SILVA, 2005, p. 410).

\title{
CONSTITUIÇÃO FEDERAL E O MEIO AMBIENTE
}

Traçado um panorama inicial sobre as questões que envolvem o meio ambiente e o comércio internacional, sob uma ótica preventiva com o objetivo de assegurar a sustentabilidade do nosso desenvolvimento, adentraremos na matéria que envolve o meio ambiente no Brasil e sua respectiva abordagem legal. Nesta perspectiva, Clarissa D'1sep (2004, p. 55) afirma que:

A proteção legal do meio ambiente veio como resposta aos vários e complexos fatores sóciopolítico-econômico-físico-tecnológicos, inicialmente apontados, e aos compromissos assumidos nos tratados internacionais. A Declaração do Meio Ambiente, adotada pela Conferência das Nações Unidas, realizada em Estolcomo, em 1972, firmou vinte e seis princípios fundamentais de proteção 
ambiental, que influenciaram a regulamentação da matéria ambiental na Constituição de 1988.

Diante da afirmação feita pela autora, podemos inferir que a nossa Constituição incorporou tais princípios e preceitos de tutela ambiental, em virtude da pressão e dos anseios sociais em relação a esta temática. Ou seja, a norma jurídica de proteção ambiental surge como uma resposta eficiente e eficaz para a sociedade, em face aos abusos e destruições causados ao meio ambiente.

Essa previsão legal - de proteção ao meio ambiente - no texto constitucional é de extrema importância, na medida em que a Constituição Federal é dotada de supremacia, eficácia plena e normas pragmáticas que possuem um respaldo vinculativo para todo o ordenamento jurídico, não devendo assim, nenhuma outra norma está em desconformidade com uma norma constitucional, sob pena de perder sua validade jurídica. Partindo desta premissa, temos que a matéria ambiental presente na Constituição significa que o Estado será o responsável por resguardar e utilizar todos os meios jurídicos para evitar a degradação desse bem.

No âmbito mundial, outros países da América Latina já disponham em seu texto constitucional um capítulo que versava sobre o meio ambiente, tais como: As Constituições do Equador e do Peru (1979), Chile e Guiana (1980), Honduras (1982), Panamá (1983), Guatemala (1985), Haiti (1987) e Nicarágua (1987). Na Europa, podemos citar o exemplo das Constituições de Portugal (1976) e Espanha (1978). (MACHADO, 2005)

Entretanto, no Brasil, somente na Constituição de 1988 que o meio ambiente adquiriu um espaço na Carta maior do nosso país. Conforme dispõe no art. 225 do Capítulo VI do Título VIII da Constituição Federal: "Todos têm direito ao meio ambiente ecologicamente equilibrado, bem de uso comum do povo e essencial à sadia qualidade de vida, impondo-se ao poder público e à coletividade o dever de defendê-lo e preservá-lo para as presentes e futuras gerações."

A partir deste caput na nossa Carta Maior, é importante ressaltar que esse dispositivo veio em resposta à luta de vários ambientalistas que acreditavam que a proteção ao meio ambiente só poderia ser efetivada com a participação de todos. Neste momento, cabe acrescentar que concomitante a luta pela causa ambiental deve-se ter uma maior valorização das instituições democráticas e do exercício da cidadania para que se possa chegar a uma conscientização ideal da população no que diz respeito ao meio ambiente.

No que diz respeito à função legislativa, ou seja, a criação de mecanismos legais que visam proteger o Meio Ambiente dentro da Constituição, Erika Pegado (2009, p. 11) profere:

A Constituição deu ao Poder Público (art. 23 e incisos, art. 24, VI e VIII), seja Federal (art. 21, XI, XIX e XX), Estadual (art. 26 e incisos) ou Municipal (art. 30, I, VII e VIII), a competência de legislar em defesa do Meio Ambiente, isto é, estabelecer normas jurídicas - leis, decretos, portarias e resoluções. Consagrou a proteção administrativa, legislativa e judicial aos bens ambientais, prevendo regras de competência (art.23), regras gerais (art. 170, VI, $173 \S 5^{\circ}$ ) e regras específicas (art. 225). 
Ainda nesta perspectiva, a Carta Magna também se preocupou com os casos em que a pessoa jurídica possa vir a cometer um crime contra o meio ambiente e materializou esse pensamento no art. $225, \S 3^{\circ}$ : "as condutas e atividades consideradas lesivas ao meio ambiente, sujeitarão os infratores, pessoas físicas ou jurídicas, a sanções penais e administrativas, independentemente da obrigação de reparar os danos causados."

Por fim, com base em toda essa previsão de proteção ambiental no texto da nossa Constituição, podemos inferir que existe uma preocupação cada vez mais crescente com a preservação do meio ambiente e seus recursos naturais, de maneira que a corrente difundida na atualidade é de um equilíbrio entre o desenvolvimento econômico e o meio ambiente, ou seja, a propagação do desenvolvimento sustentável.

\section{COMÉRCIO INTERNACIONAL}

Uma vez abordada os princípios que norteiam o Direito Ambiental e o seu respaldo no nosso ordenamento jurídico interno, devemos fazer uma breve contextualização histórica do comércio internacional ao longo dos tempos para chegarmos a um ponto de congruência entre as práticas e políticas ambientais em meio às relações comerciais entre os países.

De acordo com Pires (2001) temos que o comércio internacional é caracterizado pela "troca de bens ou serviços entre indivíduos, empresas e governos dos diversos países, tendo em vista, de um lado, a satisfação de necessidades ou o bem-estar das pessoas e, de outro, a finalidade de lucro". Diante disto, podemos inferir que essas relações comerciais já podiam ser visualizadas desde a época da Grécia Antiga e do Império Romano, constituindo-se como um fenômeno bastante antigo. Com a evolução do comércio ao longo do tempo, várias políticas econômicas e comerciais foram adotadas, cada uma com um conjunto de medidas pertinentes às necessidades da sua época.

Com isso, a comercialização internacional de produtos consiste numa maneira de suprir as necessidades do homem, substituindo a demanda dos produtos pela produção necessária. A Economia internacional abrange justamente os termos de comércio entre os países, englobando as importações e exportações utilizadas para sanar a demanda da população pelos produtos. A Economia internacional também trabalha com as barreiras do comércio internacional empregadas pelos países, as principais políticas econômicas utilizadas, bem como as teorias econômicas adotadas como suporte teórico para conduzir as ações dos países. De acordo com Maia (2003):

Não só o comércio se tornou internacional. Também outros atos humanos, relacionados com a atividade econômica, não respeitarem as fronteiras nacionais, formando um conjunto de atividades que constituem a Economia Internacional.

Nos Séculos XVII e XVIII vigorou uma vertente teórica denominada de Mercantilismo que se baseia no conceito de que as nações deveriam possuir reservas de metais preciosos para serem consideradas ricas. Nesta época, as políticas econômicas fomentavam as práticas de exportação em detrimento das importações, mesmo que esse paradigma causasse malefícios à população, o importante era aumentar o poder e a riqueza do Estado. 
No final do Séc. XVIII surge uma corrente contrária ao mercantilismo, inclusive no que diz respeito à forte intervenção do Estado na economia, conhecida por liberalismo. $\mathrm{O}$ liberalismo defendia a não intervenção-estatal, um mercado livre e sem barreiras protecionistas entre as nações. O setor mais beneficiado com essa política foi o privado, na medida em que possuía uma maior liberdade para estabelecer suas práticas no comércio doméstico e internacional. O maior precursor desta teoria foi Adam Smith e defendia que o Estado era o responsável por assegurar a concretização do livre intercâmbio entre as nações, devendo otimizar a utilização dos recursos disponíveis e promover $\mathrm{o}$ desenvolvimento econômico.

Em um período subsequente ao liberalismo, surge a teoria do pós-liberalismo que afirma que a liberalização comercial não sobreviveria enquanto o país não atingisse o pleno desenvolvimento econômico, o que justificaria uma intervenção mínima do Estado a fim de alcançar esse objetivo. Podemos inferir que essas duas teorias repercutem na nossa economia mundial até hoje e compreensão destas é de suma importância para o delineamento da dinâmica econômica e social do mundo.

Por volta do séc. XIX, em que tivemos vários acontecimentos marcantes na história, tais como guerras, crises, inovações tecnológicas, ocorreram mudanças substanciais no meio social, surgindo movimentos sindicais e empresariais decorrentes da nova produção industrial.

Além da enorme degradação ambiental provocada pela época das Revoluções industriais, esta promoveu o comércio internacional, na medida em que impulsionaram a criação de estradas, diversificação dos meios de transporte e redes de comunicação, novas rotas de navegação e consequentemente adentrarem em novos mercados. Bianchi (2008, p. 38) complementa:

\footnotetext{
São vários os fatores que contribuíram ao longo da história, e ainda contribuem, para uma degradação infrene ao meio ambiente. Entre os mais graves, estão, em primeiro lugar, o incentivo ao aumento do volume do comércio internacional, que leva consequentemente ao exercício de uma agricultura intensiva destinada ao consumo de humanos e animais; além de um consumismo sem limites nos países ricos, onde as pessoas auferem renda que lhes possibilita o consumo de "novidades" criadas constantemente pela alta tecnologia e impulsionadas pela mídia. E, em segundo lugar, os surtos de industrialização ocorridos no passado e a sua propagação no presente, bem como o incentivo a um desenvolvimento econômico às custas da harmonização do homem com o seu meio.
}

Com o advento da primeira guerra mundial, Locatelli (2003) afirma que o comércio internacional passou por um período de sérias restrições que só veio a ser amenizado por volta da década de 40. Com isso, tem-se que alguns países como Inglaterra e Estados Unidos não sofreram com a maciça destruição que assolou a Europa e galgaram a um expressivo desenvolvimento industrial.

A cerca dos efeitos causados pela primeira guerra e sua repercussão no cenário internacional, envolvendo meio ambiente e comércio, Bianchi $(2008$, p. 41) tece alguns comentários: 


\begin{abstract}
Nesse período, a teoria clássica econômica foi aplicada - mediante a lógica das vantagens comparativas, onde os Estados seguiam uma cartilha ditada pelos liberais clássicos, a fim de se acelerar o processo desenvolvimentista. Com esse sistema, a degradação do meio ambiente foi intensificada com a abertura das fronteiras agrícolas dos países em desenvolvimento, para a produção de gêneros alimentícios destinados à exportação. Absurdos foram "naturalmente" cometidos em nome da maximização comercial.
\end{abstract}

Assim, no período entre as guerras mundiais, por volta de 1929, os Estados Unidos passaram por uma terrível crise que já tinha origem na recessão econômica vivida pela Inglaterra e Canadá dois anos antes. Com isso, houve a "quebra" da bolsa de Nova Iorque, refletindo negativamente nas economias do mundo inteiro. Neste período, o desemprego atingiu índices bastante elevados, empresas faliram e fazendeiros perderam seus lotes de terra. Diante de todo esse caos, os governos - visando proteger suas economias resolveram adotar medidas protecionistas a fim de combater a crise econômica mundial.

A segunda guerra mundial teve basicamente os mesmo efeitos que a primeira, levando em consideração que houve uma grande destruição na Europa e o comércio exterior encontrava-se novamente estagnado. No pós-guerra, surge os Estados Unidos como uma super potência no mundo e com um poderio bélico e principalmente econômico que respondia por cerca de metade do Produto Interno Bruto (PIB) mundial.

Devido às consequiências lamentáveis das duas guerras mundiais, foram criados vários organismos internacionais com diversos objetivos, tais como: preservar a paz e segurança mundial, reconstrução financeira dos países e promover o multilateralismo o comércio exterior. Assim, essas instituições importantíssimas no plano internacional, são: Fundo monetário Internacional (FMI); Banco mundial e ONU. Durante este período vários acordos são firmados, destacando-se o Acordo Geral de Tarifas e Comércio (GATT) que passou a regulamentar uma parcela expressiva do comércio internacional. Por volta desse período, tivemos ainda a criação da Liga das Nações Árabes (1945) e a concretização do Plano Marshall (1947).

O auxílio de organizações internacionais conseguiu restabelecer a ordem política, econômica e militar na Europa, de modo que continuavam a surge diversos acordos como o Conselho de Assistência Mútua (Comecon), o Tratado de Paris (1951) e o Tratado de Roma (1957). Cabe ressaltar que esses tratados originaram a atual União Européia.

Nas décadas de 1950 e 1960, segundo Locatelli (2003) foi marcado pelo surgimento de processos de integração, ou seja, formação de blocos econômicos cada um com seu respectivo nível de integração e razão de existir. Já nas décadas de 1970 e 1980, o mundo vivenciou as crises ocasionadas pelas oscilações do preço do petróleo, gerando uma enorme inflação e déficit na economia de muitos países.

A partir da década de 1990 até os dias atuais, tem-se uma consolidação dos processos de integração entre os blocos econômicos, como por exemplo, a União Européia galgou mais um degrau de liberalização comercial intrabloco, a formação do Acordo de Livre Comércio da América do Norte (NAFTA) e Mercado Comum do Sul (MERCOSUL) começaram a delimitar seus objetivos com maior precisão. (LOCATELLI, 2003) 
Diante desta breve evolução histórica do comércio internacional, Bianchi (2008, p. 45) faz uma reflexão sobre a interação do comércio com o meio ambiente, sob o enfoque do paradigma capital expansionista que vivemos:

\begin{abstract}
O comércio internacional, por seu turno, abre a economia de um país à concorrência externa e modifica as condições do mercado. Como instrumento para promover o crescimento econômico, reorientar os recursos e obter economias de escala, o comércio internacional tende a modificar o comportamento dos agentes econômicos (investidores, empresários e consumidores), ampliando ou restringindo as oportunidades de negócios e empregos nos distintos setores comerciais ou industriais. Essas modificações se realizam num ambiente natural determinado, e também geram efeitos no meio ambiente.
\end{abstract}

Portanto, constata-se que ao passo que o comércio exterior está evoluindo e ficando cada vez mais competitivo, a preocupação e tutela ao meio ambiente também está crescendo, fazendo com que esses dois aspectos procurem conviver da melhor forma possível em âmbito internacional, nem que para isso seja necessária a criação de mecanismos que viabilizem esse processo, como por exemplo, as certificações ambientais.

\title{
CERTIFICAÇÕES AMBIENTAIS E O COMÉRCIO INTERNACIONAL
}

A economia mundial encontra-se em constante movimento e passível de mudanças estruturais a todo instante. Com isso, os países começaram a se acoplar para formar blocos econômicos com o intuito de aumentar seu poder de barganha, buscar novas formas de protecionismo e participar de disputas geopolíticas. Temos vários exemplos desses blocos comerciais: NAFTA, União Européia e o MERCOSUL. Cada um em sua esfera diferenciada de integração, podendo ser em vários níveis: comercial, monetária e política.

Diante deste cenário econômico global em construção, os governos dos países desenvolvidos, sejam eles isolados ou em blocos econômicos, sofrem fortes pressões para que haja um protecionismo as empresas e os produtos nacionais, com intuito de evitar o desemprego e a falência das empresas dentro do país. Ou seja, a cobrança por medidas que protejam determinados setores da economia interna do país é muito grande, tendo os governos o desafio de adotar estratégias de proteção e competitividade que atendam os interesses dos nacionais.

$\mathrm{O}$ assunto de certificações ambientais, como um requisito fundamental nas atividades comerciais, tem sido alvo de muitas inquietações, principalmente por parte dos países em desenvolvimento, na medida em que surgiram propósitos comerciais ligados a objetivos ambientais duvidosos e o sistema de certificação ambiental foi originalmente elaborado nos países desenvolvidos. Bianchi (2008, p. 184) confirma:

Esse assunto apresenta-se cada vez mais complexo, pois hoje não envolve somente os setores produtivos dos diferentes níveis de países, mas também organizações não-governamentais que trabalham na área ambiental; os consumidores, principalmente os dos países ricos, entre outras implicações. Estes fatos, sem dúvida, favorecem o sistema de certificação ambiental originalmente elaborado nos países desenvolvidos. 
Durante a Conferência do Rio (ECO-92), surgiu um grupo de especialistas - no âmbito da ISO - que seria incumbido de desenvolver normas de gestão ambiental. Dessa forma, as certificações e rótulos ambientais passaram a integrar as políticas ambientais dos países, auxiliando os consumidores a comprarem produtos provenientes de um processo ecologicamente "correto" e as empresas a adotarem medidas ecologicamente "sustentáveis".

Portanto, de acordo com Bianchi (2008) "Mais recentemente, esses instrumentos passaram a integrar o marketing da empresa que possui o certificado, representando um diferencial a mais no mercado." Isso nos remete a importância que as certificações ambientais estão adquirindo na economia internacional e como estão conferindo às empresas um diferencial de competitividade no mercado global.

\section{A CARACTERIZAÇÃO DOS PADRÕES ISO}

Antes de caracterizarmos os aspectos que formam os padrões ISO, temos que ressaltar a importância da normalização no plano internacional e acima de tudo na sociedade moderna, na medida em que facilita o intercâmbio comercial entre as nações e proporciona uma maior facilidade e conforto para o cidadão e consumidor viver em um mundo globalizado. Trata-se aqui dos benefícios advindos da aplicação de normas internacionais que acarretam no processo de padronização, que permite, por exemplo, a utilização de cartões de crédito em qualquer lugar do mundo. Uma vez dada essa breve justificativa funcional da padronização no plano internacional, adentraremos na parte histórica e posteriormente os aspectos pertinentes à finalidade, estrutura e funcionamento.

A padronização internacional começou no ano de 1906, mais especificamente no ramo da eletrotécnica com a criação da Internacional Electrotechnical Commission - IEC (Comissão Eletrotécnica Internacional). No ano de 1926, a Comissão passou a atuar também em outras áreas e com isso foi fundada a Associação Internacional de normatização (Internacional Standard Association - ISA), se extinguindo em $1942 \mathrm{em}$ razão da Segunda Guerra Mundial. A iniciativa de criar uma nova organização de normalização internacional surgiu em 1946, na cidade de Londres e contava com a participação de 25 países. Mas foi em fevereiro de 1947 que a ISO foi fundada oficialmente e desde então começou a exercer suas atividades de elaboração de Standards. Atualmente, a ISO caracteriza-se por uma organização não-governamental e possui sua sede em Genebra na Suíça. A fim de garantir a democratização das normas instituídas, esta organização é formada por representantes de 157 países diferentes.

A cerca da origem da sigla ISO, destaca-se a falta de correspondência entre esta sigla e o seu nome organizacional por extenso - International Organization for Standardization. Bianchi (2008, p. 89) apresenta a seguinte justificativa em sua obra:

\footnotetext{
Isso se explica em razão do fato de que "ISO" é uma sigla derivada do grego "isos" que significa "igual". O radical "iso" foi escolhido para ser a sigla da organização principalmente pelo fato de ela permanecer a mesma em todo o mundo, evitando excessos de acrônimos resultantes da tradução do nome da organização em cada língua nacional diferente. Já com a convenção adotada pelos criadores da organização, a sigla ISO possui forma invariável, em qualquer língua em que seja mencionada.
} 
Diante do significado da sigla ISO no contexto histórico internacional, temos a conceituação oficial desses padrões (Standards):

\begin{abstract}
São acordos documentados, constituídos de especificações técnicas e ou outros critérios estabelecidos para serem usados coerentemente como regras, orientações, ou definições de características, para assegurar que materiais, produtos, processos e serviços estejam estritamente aptos aos seus propósitos.
\end{abstract}

A partir desta definição, podemos inferir que os padrões ou "normas" instituídas pela ISO não possuem um caráter de cumprimento obrigatório, ou seja, não possuem força de lei. Refere-se a uma organização que se intitula como uma organização não-governamental e não sendo um sujeito do Direito Internacional Público.

A eficácia da implementação dessas normas é decorrente basicamente de dois fatores: preocupação mundial com as questões relacionadas ao meio ambiente e a valorização de um sistema de padronização para facilitar as relações comerciais no âmbito internacional. Sendo assim, é por esta última razão, que as empresas espalhadas pelo mundo inteiro estão adotando a padronização feita pela ISO, na medida em que a adoção dessas normas poderá servir como uma ferramenta de competitividade perante o atual cenário econômico internacional.

Sendo assim, temos que a finalidade dessa organização é promover o desenvolvimento mundial do ramo de padronização, de maneira a facilitar as trocas comerciais de mercadorias e serviços no âmbito internacional, bem como quebrar barreiras que dificultem o desenvolvimento cooperativo nas áreas científica, intelectual, tecnológica e econômica. Podemos inferir que a normalização é, sobretudo, um mecanismo de padronização fundamental criada pela sociedade moderna, a fim de que se tenha vislumbrado no resultado da divisão do processo produtivo uma maior segurança e uma proporcional determinação de responsabilidade entre os parceiros. Nesta perspectiva, o autor D'lsep (2004) afirma que a ISO cria uma linguagem comum entre os países no que diz respeito aos assuntos que a normalização visa regulamentar no espaço mundial.

Com relação à estrutura e funcionamento dessa instituição não-governamental, Bianchi (2008, p. 94) coloca com muita propriedade:

Dos trabalhos da ISO resultam acordos os quais são publicados como padrões internacionais. O trabalho é exercido com alta descentralização, por 3.093 órgãos técnicos dos quais 201 representam os comitês técnicos, 542 são subcomitês, 2.287 grupos de trabalho e 63 grupos de estudos ad hoc. Nesses comitês, representantes habilitados do setor industrial, de institutos de pesquisa, autoridades governamentais, representantes de grupos de consumidores, e de organizações internacionais de todo o mundo "discutem" o tema da padronização global.

A elaboração das normas possui todo um processo baseado em debates e votações que vão desde os grupos de trabalho até chegarem aos comitês responsáveis, passando pelas seguintes etapas: estágio de proposta (consiste basicamente em identificar a necessidade de elaboração de novas normas e submeter uma nova proposta à votação de um comitê técnico); estágio preparatório (aprovado um novo trabalho - new work item - os especialistas dos grupos de trabalho elaboram minutas do que foi desenvolvido); estágio 
de comitê (As minutas geradas no estágio de proposta são reunidas em uma nova minuta e levada a votação pelos subcomitês); estágio de aprovação (Uma vez aprovada, a minuta é registrada pelo secretariado central da ISO e dever ser aprovada por no mínimo dois terços dos membros participantes dos comitês e subcomitês, não podendo os votos negativos excederam a $1 / 4$ do total de votos) e por fim, estágio de publicação (Aprovadas todas as etapas anteriores, inclusive a norma, será elaborado um texto final).

Por fim, antes de começarmos uma abordagem mais específica sobre as normas da série ISO que dispõe sobre as questões ambientais, devemos mencionar as normas da série ISO 9000 que antecederam e versam sobre a implantação de um Sistema de Gestão da Qualidade - SGA nas empresas, com enfoque no processo de produção.

Fazendo um breve comentário sobre as normas ISO da série 9000 e de forma comparativa com a série 14.000, temos que aquelas foram criadas em 1987, para facilitar as relações comerciais e melhorar a gestão da qualidade das empresas. Esse processo de criação teve inicio com a II Guerra Mundial, na Inglaterra, produtora de armamentos, notou que muitas das bombas produzidas explodiam ou no próprio armazém ou no transporte, a partir dai o governo inglês começou a adotar um sistema de padronização da produção, a fim de diminuir os riscos durante o processo produtivo. Em 14 anos, a norma sofreu diversas modificações e atualizações, e hoje as três normas ISO 9001, ISO 9002 e ISO 9003 se unificaram na ISO 9001:2000. O órgão responsável pela distribuição da norma no Brasil é a Associação Brasileira de Normas Técnicas (ABNT).

A falta de padronização e a ausência do comprometimento com a satisfação do cliente vêm denegrindo a imagem da empresa brasileira no mercado externo, dificultando assim negociações futuras. A certificação pela norma internacional ISO 9000 tende a resgatar a credibilidade bastante abalada de nossas empresas, em um mercado internacional cada vez mais competitivo.

Nesta perspectiva, após a rápida aceitação da ISO 9000 e com o aumento dos padrões ambientais no mundo, a ISO formou o Strategic Action Group on the Environment (SAGE) no ano de 1991 com o objetivo pleitear algumas questões que envolvem: promover uma abordagem comum à gestão ambiental; facilitar o comércio e transpor barreiras comerciais e aumentar a capacidade da organização de atingir melhorias no desempenho ambiental. (D’1sep, 2004)

O SAGE, diante da grande demanda de assuntos ambientais e consciente de que era necessário um novo Comitê ISO para tratar especificamente sobre as questões dessa natureza, foi instalado em 1993 o TC-207 - Comitê Técnico 207, com o intuito de elaborar normas de Gestão Ambiental. 


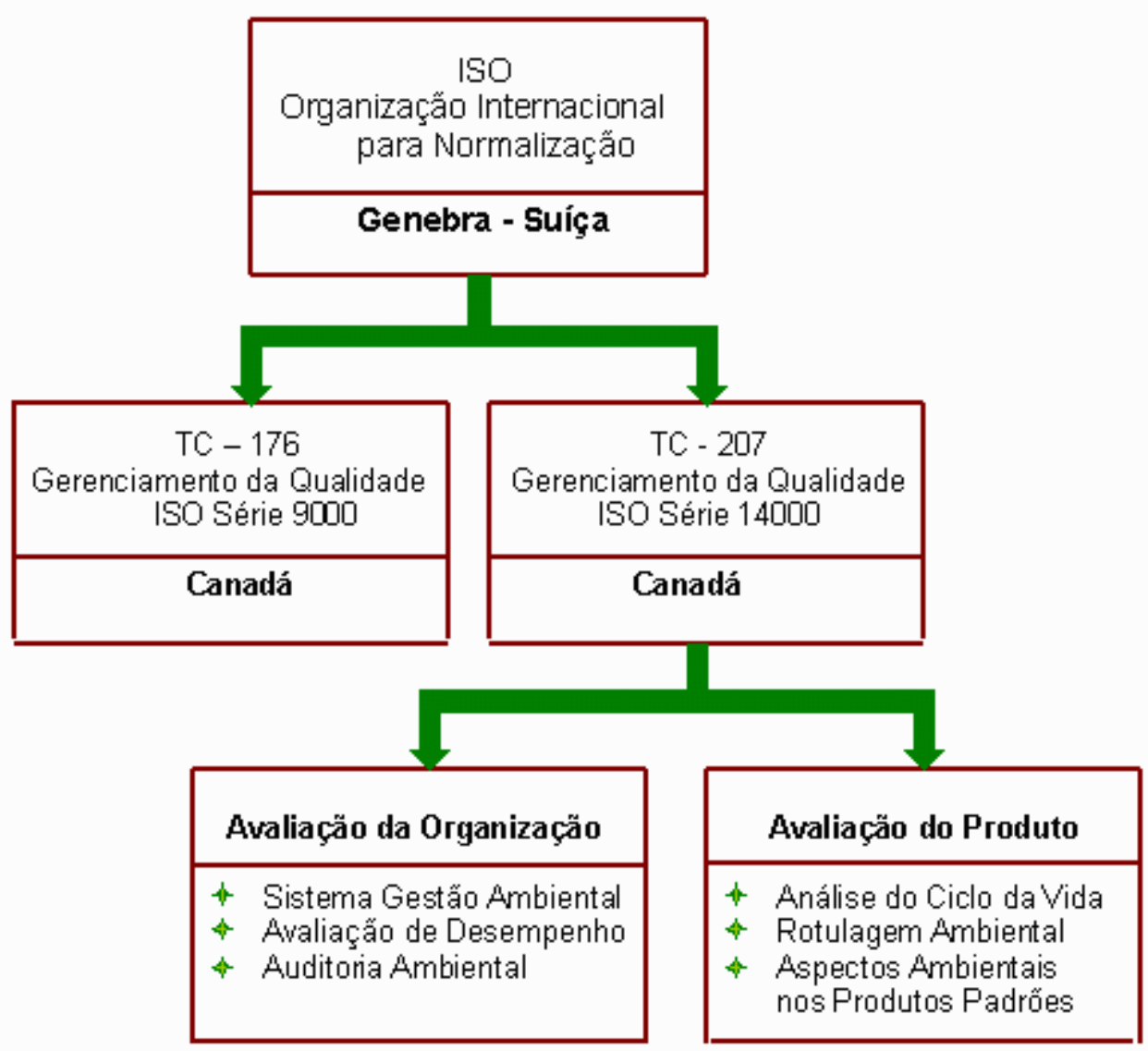

Fluxograma 1: Estrutura do Gerenciamento Ambiental (TC - 2007). Fonte: Moreira (2001).

\section{NORMAS DA SÉRIE ISO 14.000}

As normas da série ISO 14.000 compreendem um conjunto de normas ambientais, destituídas de caráter obrigatório, mas de alcance internacional, que proporcionam a obtenção de uma certificação ambiental. Entretanto, a certificação só poderá ser alcançada mediante a implementação de um Sistema de Gestão Ambiental (SGA). Com isso, a série ISO 14.000 é destinada para a aplicação em empresas que tenham por objetivo se adequar aos critérios e padrões elaborados pela International Organization for Standardization.

O Sistema de Gestão Ambiental, fundamentado na teoria dos sistemas do alemão Ludwig Von Bertalanffy - publicada em 1968, possui um funcionamento sistemático baseado na entrada, saída, interação entre essas partes e a manutenção. Nessas etapas teriam as diretrizes, políticas e normas ambientais como o início do sistema, em seguida a saída seria o produto final produzido de forma ecologicamente sustentável e existiria uma rede interna que relaciona esses dois aspectos, bem como a manutenção nesse processo significa a avaliação constante do mercado consumidor. Diante de todo esse processo, dizemos que é de suma importância para que se tenha um produto elaborado em harmonia com o meio ambiente e concomitantemente com os parâmetros impostos pelo mercado.

No que diz respeito propriamente à certificação dos sistemas de gestão ambiental, temos que surgiu efetivamente a partir da ECO-92, quando a Câmara Internacional do Comércio 
(CCI) publicou a Carta Empresarial para desenvolvimento Sustentável (anexo). Esta carta dispõe de 16 princípios de boas práticas para os empresários na matéria de gestão ambiental e ganhou uma maior importância a partir de 1992, como um verdadeiro diferencial para as empresas sobreviverem no mercado internacional.

Entretanto, em muitos ramos do setor empresarial essa questão ambiental pode ser vista como um verdadeiro empecilho para o desenvolvimento da indústria, na medida em que a adoção de práticas ambientais traria maior gasto para o orçamento da empresa e impediria a ideia de lucro máximo. Contudo, Bianchi (2008, p. 111) concorda que é preciso contrabalancear os aspectos positivos e negativos chegando a este pensamento:

Assim, defende-se que a "proteção ambiental é boa para o negócio". Todavia, sabe-se que o investimento em tecnologias limpas e a implementação de um sistema de gestão ambiental podem custar caro para uma empresa, dependendo do porte e das condições da mesma. Por outro lado, sustenta-se que abdicar dessa nova postura, hoje internacionalmente imposta, pode custar ainda mais caro.

Uma vez adotada o Sistema de Gestão Ambiental, as organizações esperam que haja uma melhoria contínua entre o setor empresarial e o meio ambiente. Ou seja, visando reduzir os impactos ambientais gerados na área de produção, transporte, uso e disposição final do produto. No entanto, antes de tomar qualquer decisão a respeito do gerenciamento ambiental da empresa, a própria deve delinear muito bem a "política ambiental" que deseja adotar e a partir disso construir um quadro de metais e objetivos ambientais a serem alcançados, correlacionados ao seu desempenho ambiental estimado.

\footnotetext{
Os "princípios" essenciais para orientar os responsáveis pela implementação ou aprimoramento de um sistema de gestão ambiental incluem: a) reconhecer que a questão ambiental se encontra entre as mais altas prioridades da organização; b) estabelecer e manter comunicação com as partes interessadas internas e externas; c) determinar os requisitos legais aplicáveis e os aspectos ambientais associados às atividades, produtos ou serviços da organização; d) desenvolver o comprometimento da administração e dos empregados no sentido de proteção ao meio ambiente, como uma clara definição de responsabilidades e responsáveis; e) estimular o planejamento ambiental ao longo do ciclo de vida do produto ou processo; f) estabelecer um processo que permita atingir os níveis de desempenho visados, de forma contínua; g) avaliar o desempenho ambiental com relação à política, objetivos e metas ambientais da organização, buscando aprimoramentos, onde apropriado; h) estabelecer um processo de gestão para auditar e analisar criticamente o Sistema de Gestão Ambiental - SGA, e para identificar oportunidades de melhoria do sistema e do desempenho ambiental resultante; i) estimular prestadores de serviços e fornecedores a estabelecer um SGA”. (BIANCHI, 2008, p.115).
}

Diante de todos esses princípios e regras procedimentais de gestão ambiental, estes podem se materializar através da adoção de um ciclo conhecido por PDCA (Plan, Do, Check, Act) conforme as diretrizes da ISO 14000. Para isso, faz-se necessário como ponto inicial o comprometimento da alta administração da organização, bem como a formulação de uma política ambiental. Com isso, a empresa poderá visualizar melhor o processo de gerenciamento e desempenho do SGA. Para melhor ilustração dos aspectos recémabordados, temos: 


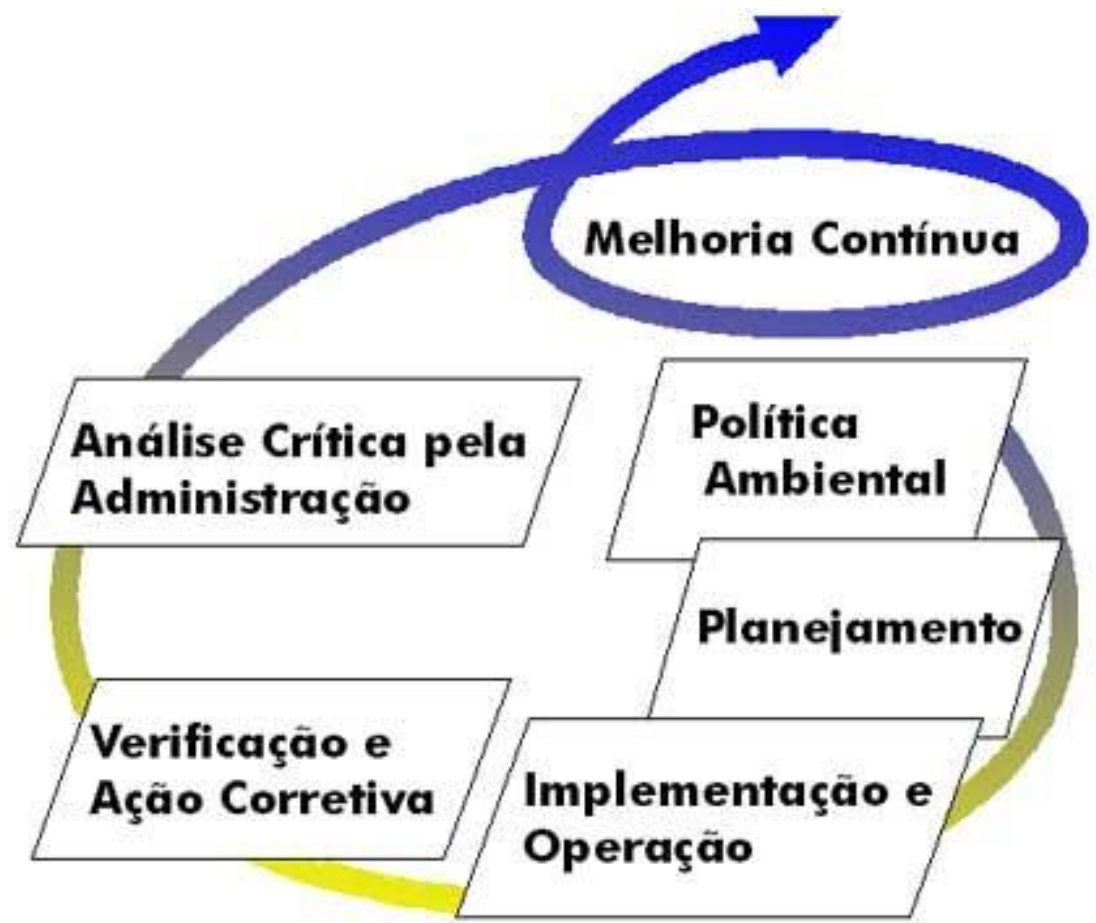

Ilustração 1: Ciclo PDCA para o sistema de gestão ambiental - ISO 14001.

Fonte: Werkema (1995).

Devemos ressaltar outro aspecto muito importante no que consiste a aceitação e adesão de todo esse processo por uma organização. Cabe dizer que a mudança de postura das empresas com relação à preservação dos recursos naturais, é decorrente mais de uma exigência mercadológica e de competitividade no mercado, do que propriamente da formação de uma consciência ecológica no sentido de tutelar os recursos ambientais para as próximas gerações.

Por fim, podemos inferir que a sério ISO 14000 sendo um conjunto de normas ambientais facultativas, em último caso, visam contribuir para um aumento da qualidade de vida do meio ambiente, de maneira que se pode afirmar que o somatório das contribuições individuais das empresas ambientalmente corretas contribui para o desenvolvimento sustentável em nosso planeta.

\section{AS EMPRESAS FRENTE ÀS CERTIFICAÇÕES AMBIENTAIS}

Tendo em vista que os diversos países que integram o mercado mundial possuem realidades diferentes - ecossistemas diferentes, grau desenvolvimento sustentável distinto e política ambiental própria - quando um país desenvolvido cria um sistema de certificação ou rotulagem ambiental está colocando os seus "próprios critérios" para servir como parâmetro, podendo tornar-se uma barreira comercial não tarifária.

Com isso, as empresas possuem algumas alternativas frente às certificações e rotulagens ambientais. Elas podem adotar uma postura de indiferença a tais programas; aceitar e participar dos programas, pressionadas pelas questões relacionadas à competitividade no mercado e buscar a certificação, com o intuito de influenciar na produção dessas normas. 
A postura de indiferença de uma empresa frente a um programa de certificação não é o mais aconselhável, pois os consumidores e o mercado estão ficando altamente conscientes sobre os danos ambientais e exigindo que as empresas comprovem o seu comprometimento com um meio ambiente saudável.

A segunda opção consiste na adesão de uma certificação ambiental pela empresa. Entretanto, a empresa deve estar ciente que essa decisão envolve alguns gastos para adaptação interna a um Sistema de Gestão Ambiental, devendo arcar com os custos da implementação de uma tecnologia apropriada e funcionários capacitados para desempenhar a política ambiental na empresa.

$\mathrm{Na}$ terceira opção, temos que uma empresa escolhe se certificar em virtude da possibilidade de participar do processo de elaboração das normas ambientais. Esse desejo surge da vontade que as empresas possuem - principalmente aquelas oriundas dos países em desenvolvimento - de tornar o procedimento mais democrático.

\title{
BARREIRAS COMERCIAIS AMBIENTAIS
}

Uma das grandes preocupações dos países em desenvolvimento em relação à implementação de um sistema de certificação e rotulagem ambiental consiste na possibilidade de estas criarem barreiras comerciais, propositalmente ou não, ao comércio internacional. Isto ocorre devido ao sistema de normas ambientais serem formuladas pelos países desenvolvidos e, portanto apresentarem um perfil tendencioso aos interesses comerciais destes. Para tanto, a maior das críticas direcionadas aos selos e órgãos de normalização ecológica consiste em afirmar que estes "[...] abrigam tendenciosidades e imprecisões, favorecendo setores produtivos, acarretando em severos prejuízos aos concorrentes instalados nos países em desenvolvimento". (BIANCHI, 2008)

Diante desta problemática, essa nova barreira comercial está levando para a harmonização internacional dos sistemas de certificação, a ser supostamente organizada pela ISO. Essa harmonização possivelmente facilitaria as trocas comerciais entre os países, conforme opinião da Organização Mundial do Comércio que aposta na idéia. O autor Barbieri (2007, p. 205) aposta nesta ideia ao afirmar que:

\begin{abstract}
A normalização de um modo geral desempenha um papel fundamental nos processos de produção e distribuição, podendo facilitar ou criar obstáculos ao comércio internacional. A existência de várias normas de âmbito nacional sobre uma mesma matéria constitui uma barreira ao comércio, pois aumenta os custos do exportador que pretende atender a mais de um mercado. Uma norma internacional gera economia de recursos para o produtor e maior segurança para o consumidor e torna mais ágil o comércio entre as nações, pois permite simplificar e uniformizar procedimentos administrativos e operacionais.
\end{abstract}

Entretanto, mesmo que a ISO venha a assumir a construção de um sistema de harmonização de normas ambientais internacionais, ainda sim teria muitas tendenciosidades. Sendo assim, o que deve ser alvo de preocupação e mudança na formulação de normas ambientais de cunho internacional são os critérios utilizados para a elaboração das normas e requisitos a serem cumpridos pelas empresas. A política ambiental deve ser projetada de forma que respeite a realidade de cada país. 
Os critérios para elaboração de rotulagem ou certificação dos produtos podem, muitas vezes, apresentar-se como uma verdadeira barreira comercial. Isto se deve ao fato de que a criação de categorias atenda aos interesses de determinados setores produtivos dos países desenvolvidos (onde tais normas são elaboradas). Levando em consideração a posição dos países em desenvolvimento dentro deste sistema, Bianchi (2008, p. 197) indaga:

\begin{abstract}
Trata-se de uma situação de grande risco para produtores dos países em desenvolvimento que não participam da formação dos critérios, e são impedidos de comercializarem seus produtos por determinação unilateral de blocos econômicos mais estruturados, ou mesmo por alguns países desenvolvidos. A aplicação de penalidades resultantes desses critérios a um país como o Brasil não modificará o problema europeu, e criará mais uma barreira a um exportador que possui uma realidade ambiental e socioeconômica diferente. Assim, verifica-se que alguns critérios penalizam a produção de alguns países em desenvolvimento, tirando-lhes as suas vantagens competitivas.
\end{abstract}

Com o intuito de solucionar questões que possam surgir de critérios elaborados com base no interesse de determinados países, levando em consideração o seu setor produtivo, temos a difusão de uma ideia baseada na harmonização internacional dos sistemas de certificação e rotulagem. Dentro desse sistema, inclui-se principalmente a harmonização de normas ambientais, tendo em vista a expressividade que o desenvolvimento econômico em parceria sustentável com meio ambiente está ganhando no mercado internacional.

Tendo em vista que a finalidade da Organização Mundial do Comércio (OMC) é promover a maior liberalização do comércio e dificultar a imposição de barreiras comerciais, temos que a ideia de harmonização no âmbito normativo está sendo bastante aceita. Com isso, podemos inferir que esta organização supramencionada adota basicamente dois princípios com relação aos sistemas de certificação/rotulagem ambiental. Temos que o processo de normas e regulamentos deve ser totalmente transparente, sendo de conhecimento geral de empresas e Estados, caracterizando o Princípio da transparência. O segundo princípio consiste na não-discriminação do produto estrangeiro, que visa assegurar um tratamento similar dos produtos importados com relação aos nacionais.

Contudo, essa proposta de harmonização normativa dos sistemas de certificação em âmbito global possui alguns pontos desfavoráveis que devem ser levados em consideração.

Essa ideia não reconheceria a disparidade das realidades que existem entre os países desenvolvidos e os em desenvolvimento, seja quanto à produção, preservação ambiental, socioambientalismo ou qualquer que seja a área atingida. Como também, os países desenvolvidos teriam que involuir nos seus padrões e regras para conseguir um nivelamento com os países em desenvolvimento. Questiona-se como terceiro aspecto a própria ISO como instuição competente para este trabalho.

Por fim, paira uma discussão importantíssima a cerca do poder soberano dos Estados em decidir as medidas que mais se adéquam ao seu sistema nacional e sua realidade cultural, com a possibilidade de se submeter a normas de padronização internacional. Sobre este dilema, temos:

Nenhum consenso ainda foi obtido a respeito do limite existente entre, por um lado, a promoção legítima dos benefícios comerciais assegurando-se a proteção 
do meio ambiente, e por outro, as atividades com interesses protecionistas. Contudo, observa-se que o processo de harmonização das normas ambientais em âmbito internacional não respeita a diversidade natural dos países que participam desse sistema, assim como esbarra no direito soberano de que cada Estado dispõe para elaborar e implementar a sua própria política ambiental. (BIANCHI, 2008, p.203)

\section{DUMPING}

O comércio internacional é um fenômeno bastante dinâmico e complexo, sendo a relação entre os Estados, objeto de vários acordos em geral e passíveis de regulamentação, como por exemplo, temos os Acordos do GATT ("General Agreement on Tariffs and Trade" Acordo Geral de Tarifas Aduaneiras e Comércio) e o de Marrakesh (1994). Tais acordos tem por objetivo estabelecer um conjunto de normas regulamentadoras que promovem um sistema de comércio mais justo e vantajoso para todos os Estados-Membros. Nesta perspectiva, as práticas relacionadas ao Dumping tem sido combatidas arduamente, ao longo dos anos, pelo GATT e posteriormente pela OMC.

Sendo assim, sabendo que no cenário do comércio internacional - em pleno séc. XXI alguns agentes econômicos ainda praticam determinadas ações comerciais que são consideradas desleais, podemos conceituar o dumping como:

\footnotetext{
A discriminação de preços entre dois mercados nacionais, entre o mercado exportador e o mercado importador. Entre outras palavras, o preço demandado por um determinado bem, pelo mesmo produtor, difere entre dois mercados, desconsiderando-se os fatores relacionados a transporte, tributos etc. (BARRAL, 2000, p.391)
}

Basicamente, o dumping consiste em uma prática considerada desleal de um determinado país que exporta um produto com um preço aquém do valor padrão ou "normal" dentro país importador. Esses produtos exportados com preços inferiores podem causar um impacto bastante negativo no país ao qual estão sendo destinados, na medida em que promove a ruína de várias empresas nacionais e impede a instalação de novas empresas no ramo. Todo esse efeito reflete destrutivamente na economia do país importador, bem como atinge diretamente o padrão de vida dos seus habitantes, fazendo com que haja a extinção de várias empresas e postos de trabalhos.

Podemos caracterizar a prática de dumping a partir dos seguintes requisitos: o preço de determinado produto, deve ser menor no mercado exportador do que no mercado de origem; o país importador deverá provar que a prática com dumping provocou um dano ou ameaça de dano à sua indústria nacional; e ainda deve comprovar o nexo de causalidade entre o dano causado e a suposta prática de dumping proveniente do país exportador.

Diante da preocupação do GATT/OMC com os impactos negativos provenientes do Dumping em alguns países, cria-se o art. VI do Acordo geral, assegurando às partes contratantes a faculdade de aplicar as medidas antidumping caso haja uma situação em que se caracterize essa prática desleal.

Cabe assinalar que o processo de utilização das medidas antidumping deve ser investigado de maneira profunda e com a participação das partes envolvidas, de maneira que tendo sido 
preenchido todos os requisitos estabelecidos pela OMC, as decisões serão levadas ao conhecimento público através do ato subscrito pelas autoridades competentes. E se o país for questionado internacionalmente, deverá estar disponível para consultas e defender-se perante as acusações. Vale salientar, ainda, que as práticas antidumping são muito debatidas por autores liberais, pois estas podem provocar um determinado protecionismo emergente, o que bate contra a teoria do livre-comércio entre as nações. (BIANCHI, 2008)

\section{DUMPING ECOLÓGICO}

Uma vez conceituado o que é dumping e os seus respectivos efeitos, o dumping ecológico ou ambiental consiste em enquadrar determinados países que não estão em conformidades com as normas e práticas ambientalmente corretas, como por exemplo, a utilização inconsciente e insustentável dos recursos naturais, bem como a sobre-utilização destes recursos do meio ambiente.

É importante destacar que as certificações ambientais estão diretamente relacionadas com o dumping ambiental. As certificações ambientais possuem a função de garantir que as empresas cumpram as normas de controle ambiental e assumam os custos ambientais. A lógica funciona da seguinte maneira: as certificações ambientais atestam que uma determinada empresa está arcando com os custos ambientais e, por isso, encarecendo um pouco o seu produto final, entretanto aquelas empresas que não internalizam os custos ambientais, produzindo de forma mais barata o produto, pratica uma competitividade desleal, ou seja, uma espécie de dumping ecológico.

Nesta perspectiva, analisando o impacto que essas práticas de dumping ecológico pode causar num mercado competitivo e globalizado, Bianchi (2008, p. 212) coloca:

\footnotetext{
Assim, acredita-se que esse argumento poderá servir aos interesses dos que com base nas regras do capitalismo - não conseguem manter-se competitivos; realizando-se práticas protecionistas em defesa de suas economias internas. Esses fatos representam dois movimentos contraditórios existentes no campo das relações comerciais internacionais, onde as vantagens ou desvantagens desse sistema estão sendo discutidas no âmbito da Organização Mundial do Comércio, no meio acadêmico etc.
}

Por fim, diante dessa prática desleal que poderá existir dentro das relações comerciais entre os países, dizemos que a harmonização de normas, procedimentos de avaliação da conformidade, regulamentos técnicos podem ser uma alternativa bastante eficaz para que exista um comércio "limpo" entre os Estados. Entretanto, devemos ficar sempre atentos sobre determinadas alternativas que também contribuam com a causa da sustentabilidade ambiental, sobretudo.

\section{OS BENEFÍCIOS E O DIFERENCIAL DE COMPETITIVIDADE PARA AS EMPRESAS CERTIFICADAS}

O mundo dos negócios está cada vez mais competitivo. Para se adequar a essa realidade, a empresa que quiser se destacar no mercado, deverá se aliar aos conhecimentos da Administração e gestão empresarial. 
O conceito de gestão muitas vezes se confunde com o conceito de administração. Em linhas gerais, pode-se dizer que a Administração é uma forma de gerenciar atividades e ações a fim de obter metas estabelecidas anteriormente. Gerir seria nada mais que um modelo de trabalho, encaminhado por uma política de valores, capaz de planejar, alocar e gerir recursos, ações, iniciativas, princípios, valores e estratégias, visando viabilizar o alcance dos objetivos propostos por uma organização. Segundo Chiavenato (2004, p.8): "Toda organização precisa ser administrada para alcançar objetivos com a maior eficiência, economia de ação e recursos, e ser competitiva."

Sabemos que uma empresa bem-sucedida no mercado deve necessariamente ter um bom plano organizacional e administrativo. Para isso, a empresa busca artifícios inovadores e estratégias competitivas para alcançar seus objetivos, sendo estes, que lhe permitam uma posição privilegiada e de destaque frente aos concorrentes. Segundo Rezende e Tachizawa (2000):

O grande objetivo de toda organização é ter uma forte posição competitiva, o que significa elevar as barreiras à entrada de novos competidores, engendrar um perfil de potencialidades maior e melhor do que o perfil dos seus concorrentes; tornar seu perfil compatível ou sinônimo de fatores-chave de sucesso do setor; ter um conjunto competente de estratégias competitivas inerentes; aumentar a integração ou o poder de barganha em relação aos fornecedores e intermediários e por último, ter uma alta participação no seu segmento de mercado.

Considerando o pensamento de Rezende, existem diversos fatores condicionantes específicos e não-específicos que culminam para o bom desempenho de uma organização num ambiente comercial e competitivo, tais como: o planejamento empresarial, o escopo, a análise interna e externa, bem como, a estratégia competitiva e de crescimento.

O planejamento empresarial consiste em um dos fatores mais importantes dentro de uma empresa, pois é fundamental que se defina as metas: o objetivo final, os recursos e as ações necessárias para onde se quer ir ou chegar. Sendo assim, o planejamento aparece como uma forma de atingir alternativas viáveis e estratégicas para a empresa, visando sempre minimizar os erros e ordenar as atividades para alcançar os objetivos. No que diz respeito a esse pensamento, Nascimento (2008, p. 53) complementa:

\footnotetext{
Pode-se dizer que é raro que uma única organização seja fornecedora de um determinado produto ou serviço. Geralmente, os gestores precisam descobrir o que seus concorrentes estão fazendo para, dessa forma, prever o que eles poderão fazer no futuro. Essas atividades referem-se ao ambiente competitivo, e o objetivo da análise do ambiente competitivo é ajudar as organizações a desenvolver uma vantagem competitiva, isto é, a capacidade de ter um desempenho melhor do que o dos concorrentes na oferta de algo que o mercado valorize. As organizações fazem isso entregando um valor maior, seja baixando os custos de compra e uso, seja oferecendo maiores benefícios.
}

O escopo de uma organização é a parte ideológica e funcional que esta empresa representa na sociedade. A missão, a visão e os valores permanentes de uma empresa são vertentes que compõe esse escopo. Já a análise interna e externa consiste num diagnóstico sobre os fatores que interferem dentro e fora de uma empresa, o microambiente e o macroambiente. No âmbito interno, são analisados os pontos fortes, fracos e o potencial dentro da empresa, como ela está organizada e estruturada nas suas áreas funcionais. No âmbito externo, 
existem forças que influenciam no caminho que a empresa deve seguir, são elas: demográficas, econômicas, naturais, tecnológicas, políticas e culturais. Para isso, faz-se necessário um monitoramento das estratégias usadas pelas concorrentes e estar atento ás necessidades dos consumidores no mercado.

A estratégia competitiva e de crescimento está diretamente relacionada com o poder de inovação em algum segmento do mercado, algum lançamento mais competitivo que proporcione a conquista de novos clientes, promovendo a expansão e o crescimento da organização. Portanto, denominam-se estratégias, o conjunto de medidas que apresentam um impacto positivo para a empresa e que levem em consideração as variáveis que influenciam no macro e microambiente, fazendo com que essa empresa seja diferenciada dos seus concorrentes, tenha uma posição de liderança e consiga atingir seu mercado-alvo. Ou seja, o estabelecimento de objetivos e ações que alcancem efeitos no ambiente de negócio, proporcionando uma vantagem competitiva no local em que a empresa atua ou pretender atuar (BARBIERI, 2007).

Com relação a essa aplicação consciente de estratégias competitivas e direcioná-las para alcançar determinados objetivos, Ghoshal (2004, p. 226) diz:

\begin{abstract}
Essa clareza de objetivos estratégicos é essencial para canalizar a chama empreendedora no desenvolvimento corporativo como um todo. Na ausência de uma missão estratégica claramente definida e amplamente comunicada, os gestores da linha de frente ficam sem uma base para selecionar as oportunidades com que se deparam. Logo, degenera o espírito empreendedor nos escalões mais baixos da pirâmide hierárquica, e tudo passa a ser um jogo frustrante de palpites e adivinhações. Os objetivos mais apropriados tendem a ser suficientemente precisos, de modo a eliminar claramente atividades que não dão apoio à missão estratégica da empresa.
\end{abstract}

Por sua vez, a competitividade moderna está exigindo cada vez mais que empresas e as indústrias se adéquem a uma tendência que está se consolidando no mercado internacional que é a preocupação com o meio ambiental. Essa tendência ambiental está delimitando o comportamento de muitas organizações - fazendo surgir as "indústrias verdes"- que pretendem tornarem-se mais competitivas no mercado internacional. Para isso, faz-se necessário o direcionamento das suas atividades à criação e desenvolvimento de processos, programas, e equipamentos antipoluidores que visam diminuir ou eliminar o impacto maléfico no meio ambiente.

Com relação à reação de empresas mais experientes no mercado diante da tendência ambiental que está se disseminando como estratégia competitiva no mercado, Kraemer (2005) afirma:

Empresas experientes identificam resultados econômicos e resultados estratégicos do engajamento da organização na causa ambiental. Estes resultados não se viabilizam de imediato, há necessidade de que sejam corretamente planejados e organizados todos os passos para a interiorização da variável ambiental na organização para que ela possa atingir o conceito de excelência ambiental, trazendo, com isso, vantagem competitiva. 
Diante das exigências e pressões que o mercado internacional na modernidade está fazendo para que as empresas adquiram uma consciência ecológica, torna-se cada vez mais comum a adoção de um Sistema de Gestão ambiental (SGA) nas organizações. Para tanto, temos que a implementação desse Sistema deverá estar em conformidade com os itens previstos nas normas da série ISO 14000, dispondo a empresa da liberdade e flexibilidade de adotar um modelo que seja adequado para sua realidade.

\title{
SISTEMA DE GESTÃO AMBIENTAL (SGA)
}

As exigências atuais no mercado, especialmente em âmbito internacional, estão fazendo com que muitas empresas procurem obter um maior desempenho na área ambiental, de maneira a adotar requisitos e procedimentos internos que por muitas vezes podem ser mais rigorosos do que os impostos legalmente pelo país sobre esta matéria. Portanto, podemos inferir que esses Sistemas de gerência Ambientais atuais surgiram em decorrência da exigência dos consumidores por uma maior qualidade, culminando no desenvolvimento dos Sistemas de Qualidade.

Com isso, temos que o Sistema de Gestão Ambiental dispõe de toda a sistemática necessária para que uma organização possa estruturar o seu planejamento de desempenho ambiental, por meio da alocação de recursos, atribuição de responsabilidade, avaliação contínua de suas práticas, procedimentos e processos. Sobre este assunto, Barbieri (2007, p. 204-205) discutiu com muita propriedade:

\begin{abstract}
Um SGA requer a formulação de diretrizes e o envolvimento de todos os segmentos da empresa para tratar das questões ambientais de modo integrado com as demais atividades da empresa. Segundo a norma ISO 14001, uma organização que possua um SGA poderá equilibrar e integrar interesses econômicos e ambientais e alcançar vantagens competitivas significativas. Um dos objetivos explícitos das normas ISO em geral é contribuir para eliminar as barreiras técnicas injustificadas de acordo com as novas regras de comércio internacional pós Rodada Uruguai. Tem sido voz corrente afirmar que a certificação do SGA constitui um pedágio que a empresa deve pagar para poder participar desse mercado.
\end{abstract}

Cabe esclarecer que o SGA não possui nenhum caráter compulsório, ou seja, não possui obrigatoriedade vinculativa a nenhuma legislação interna, tendo a empresa a faculdade de adotá-lo ou não como ferramenta estratégica. Entretanto, como a temática ambiental e os programas de gestão nesta área estão ganhando força no cenário internacional, espera-se a adesão do maior número de empresas a esse sistema que desejem ser competitivas no mercado.

Uma vez que esse Sistema seja adotado na organização, requer mudança na cultura e na própria estrutura organizacional, sendo uma questão que envolve não só os setores e departamentos internos, como também cada membro da empresa. Em consonância com o pensamento de Ghoshal (2004, p. 227) sobre a necessidade de uma mudança profunda de valores sociais dentro de uma empresa, temos:

A necessidade de mudança não se deve apenas a fatores competitivos, macroeconômicos ou tecnológicos. Anos de dificuldades desencadearam uma profunda mudança de valores sociais nas empresas, com a migração de um ideal 
burocrático para um empreendedor. Não se trata apenas do fato de grandes organizações burocráticas estarem sendo substituídas por pequenas empreendedoras. O ideal da burocracia caiu do trono como fonte do progresso econômico, justamente quando o espírito empreendedor começou a surgir como herói na dramaturgia da destruição criativa.

Diante disto, podemos elencar cinco estágios fundamentais que tem por objetivo promover a melhoria contínua do desempenho ambiental na empresa:

\begin{tabular}{|c|c|}
\hline Etapa 1 & Comprometimento e Definição da Política Ambiental. \\
\hline Etapa 2 & $\begin{array}{l}\text { Elaboração do Plano. } \\
\text { - Aspectos Ambientais e impactos ambientais associados. } \\
\text { - Requisitos legais e corporativos. } \\
\text { - Objetivos e metas. } \\
\text { - Plano de ação e programa de gestão ambiental. }\end{array}$ \\
\hline Etapa 3 & $\begin{array}{l}\text { Implantação e Operacionalização } \\
\text { - Alocação de recursos. } \\
\text { - Estrutura e responsabilidade. } \\
\text { - Conscientização e treinamento. } \\
\text { - Comunicações. } \\
\text { - Documentação do sistema de gestão. } \\
\text { - Controle operacional - programas de gestão específicos. } \\
\text { - Respostas às emergências. }\end{array}$ \\
\hline Etapa 4 & $\begin{array}{l}\text { Avaliação Periódica } \\
\text { - Monitoramento. } \\
\text { - Ações corretivas e preventivas } \\
\text { - Registros. } \\
\text { - Auditorias do sistema de gestão }\end{array}$ \\
\hline Etapa 5 & Revisão do SGA \\
\hline
\end{tabular}

\section{Quadro 1: Etapas do Sistema de Gestão Ambiental} Fonte: Padoin (2010).

Alguns autores defendem que o maior objetivo de um Sistema de Gestão Ambiental deve ser que ao adotar medidas que vise práticas ambientalmente corretas, a empresa diminua os impactos que suas atividades, produtos ou serviços possam causar ao meio ambiente e ao próprio ser humano. Sobre esse aspecto, Silva (2008) comenta:

Se existe as condições necessárias para implantação do SGA, então a decisão mais correta é implantá-lo e para isso deverão ser contratadas pessoas capacitadas, e criada uma comissão multidisciplinar, para avaliar cada item necessário, de forma a atender os preceitos exigidos, não só pelas normas, mas, o que realmente é importante para a saúde da empresa, dos funcionários e do meio ambiente. Neste projeto deve-se dimensionar corretamente os equipamentos utilizados, treinar e qualificar dos funcionários e projetar instalações adequadas conforme normas pertinentes ao assunto, e sejam administrados ou supervisionados por profissionais comprometidos com os objetivos, para garantir a qualidade final, e para isto é necessário fazer um planejamento adequado as suas necessidades.

Nesse contexto, a certificação ambiental (série ISO 14000) possui uma relação direta com o Sistema de Gestão Ambiental, na medida em que irá avaliar esse sistema adotado dentro 
da organização e se estão em conformidade com os requisitos mínimos exigidos pela normalização internacional previamente convencionada.

\section{VANTAGENS COMPETITIVAS PROVENIENTES DA IMPLANTAÇÃO DO SGA}

Atualmente, estabelecer relações de negócios não engloba somente a venda de um produto ou serviço para mercados próximos. A rede de negociações é bastante complexa e estendese globalmente, trazendo a necessidade de se ter um conjunto de regras padrão que possam facilitar o comércio entre os países. Concomitantemente, essas regras padronizadas dever ser suficientemente flexíveis a ponto que as empresas em qualquer parte do mundo possam aplicá-las.

Em uma realidade em que o mercado global encontra-se cada vez mais competitivo e voraz, as empresas devem ser capazes de adotar estratégias eficientes para se diferenciar de suas concorrentes. A adoção de um Sistema de Gestão Ambiental (SGA) tem se mostrado como uma ótima ferramenta para que as empresas possam evoluir da básica conformidade com regulamentos para uma posição de melhor produtividade e maior vantagem competitiva. Nesta perspectiva, tem-se percebido que as empresas que adotaram esse sistema de conformidade com o meio ambiente adquiriram uma estrutura mais sólida e capacidade de gerenciar melhor os fatores internos que interferem no desempenho econômico da empresa.

No que tange aos benefícios causados pela certificação ISO 14000 para uma empresa, podemos destacar as esferas econômica, ambiental e social que sofrem o impacto direto desse sistema de normas ambientais.

Do ponto de vista econômico, a implementação da gestão ambiental pode oferecer outras vantagens para a empresa e também para o cliente. Entre as vantagens para a empresa está a criação de uma imagem "verde"; acesso a novos mercados; redução e/ou eliminação de acidentes ambientais, evitando, com isso, custos de remediação; incentivo ao uso racional de energia e dos recursos naturais; redução do risco de sanções do Poder Público (multas) e facilidade ao acesso a algumas linhas de crédito. Referente aos consumidores, estes possuirão maiores informações sobre a origem da matéria-prima e composição dos produtos, podendo optar, no momento da compra, por bens e serviços menos agressivos ao meio ambiente. (VALLE, 1995)

Já na esfera ambiental, o SGA poderá proporcionar o desenvolvimento de processos produtivos mais limpos e incentivar a produção de produtos que não agridam tanto o meio ambiente. Uma das medidas que podem ser adotadas é o incentivo à reciclagem e uso racional dos recursos naturais.

Por último, temos o ponto de vista social, que está intimamente relacionada à visão ambiental, na medida em que medidas como a correção de problemas ambientais, condições de trabalho, mau cheiro, dentre outros, refletem significativamente no setor social.

Com isso, o SGA traz diversas vantagens competitivas para as empresas que optam por internalizá-lo, tais como: criação de uma imagem "verde", a diminuição dos custos internos, aumenta a competitividade e facilita o acesso a mercados consumidores. 
Abordando sobre os incentivos que levam a empresa a implantar um SGA, Hojda (1998) apud Kraemer (2005):

\begin{abstract}
Refere que todo o desenvolvimento de normas voltadas ao Sistema de Gestão Ambiental teve aspectos importantes, ao demonstrar que o correto estabelecimento da Gestão Ambiental, além de responder às exigências da comunidade mundial e do consumidor-cidadão, também oferece às organizações vantagens competitivas matematicamente mensuráveis: redução de custos, em função da economia de recursos naturais e diminuição da geração de resíduos; possibilidades de conquistar mercados restritos, como o da União Européia; economia de recursos pertinentes a indenizações por responsabilidade civil; mais facilidade para obtenção de financiamentos junto a organismos multilaterais de crédito, como o Banco Mundial (BID), Banco Interamericano de Desenvolvimento (BIRD) e o Banco Nacional de Desenvolvimento Econômico e Social (BNDES) e atendimento às legislações inerentes ao meio ambiente.
\end{abstract}

Temos que destacar que apesar de as empresas estarem aderindo cada vez mais à adoção de Sistema de Gestão Ambiental, não significa que seja por uma conscientização puramente ecológica, em que não pese outras questões como: enquadrar-se na legislação ambiental do país, evitando sanções; possuir um diferencial competitivo no mercado para aumentar seus lucros e diminuir os custos internos visando uma otimização da produção.

\title{
GESTÃO AMBIENTAL
}

Qualifica-se como Gestão ambiental o comportamento reativo de uma organização em decorrência das exigências legais para implantar determinados mecanismos e sistemas tecnológicos que amenizem, reduzam ou eliminem certos resíduos que venham a causar algum dano ambiental.

A palavra gestão é derivada do grego "gestain" que sinifica conduzir, que possui como sinônimos em nosso idioma: governo, administração, gerenciamento e controle. Por ambiente, temos que é o espaço ou lugar em que vivemos, portanto gestão ambiental constitui-se em um processo formado de interesses e conflitos entre todos os agentes que atuam "no" e "sobre" o meio ambiente, sejam naturais ou pela conduta ativa ou omissiva do homem. Essa participação irá delimitar o modo de como os agentes, pelas suas ações, modificam a qualidade deste ambiente, levando em consideração a segurança e proteção de todos os envolvidos diretamente ou indiretamente com a empresa e com todo seu entorno, preocupando-se com o presente e com as gerações futuras. (VALLE, 1995)

Sabendo que a Gestão ambiental dentro de uma empresa, objetiva uma maior qualidade ambiental desejada, esta consiste em um conjunto de medidas que possibilitam ter o controle sobre o impacto ambiental de uma determinada atividade. Kraemer (2005) acrescenta:

A gestão ambiental começa a ser encarada como um assunto estratégico dentro das organizações e isso tem se tornado um fator importante de competitividade. Os instrumentos de gestão ambiental objetivam melhorar a qualidade ambiental e o processo decisório. São aplicados a todas as fases dos empreendimentos e podem ser: preventivos, corretivos, de remediação e pró-ativos, dependendo da fase em que são implementados. 
Como forma de ilustrar esquematicamente o modelo de gestão ambiental a ser implantando em uma empresa, visando à melhoria contínua da organização no seu desempenho funcional e ambiental:

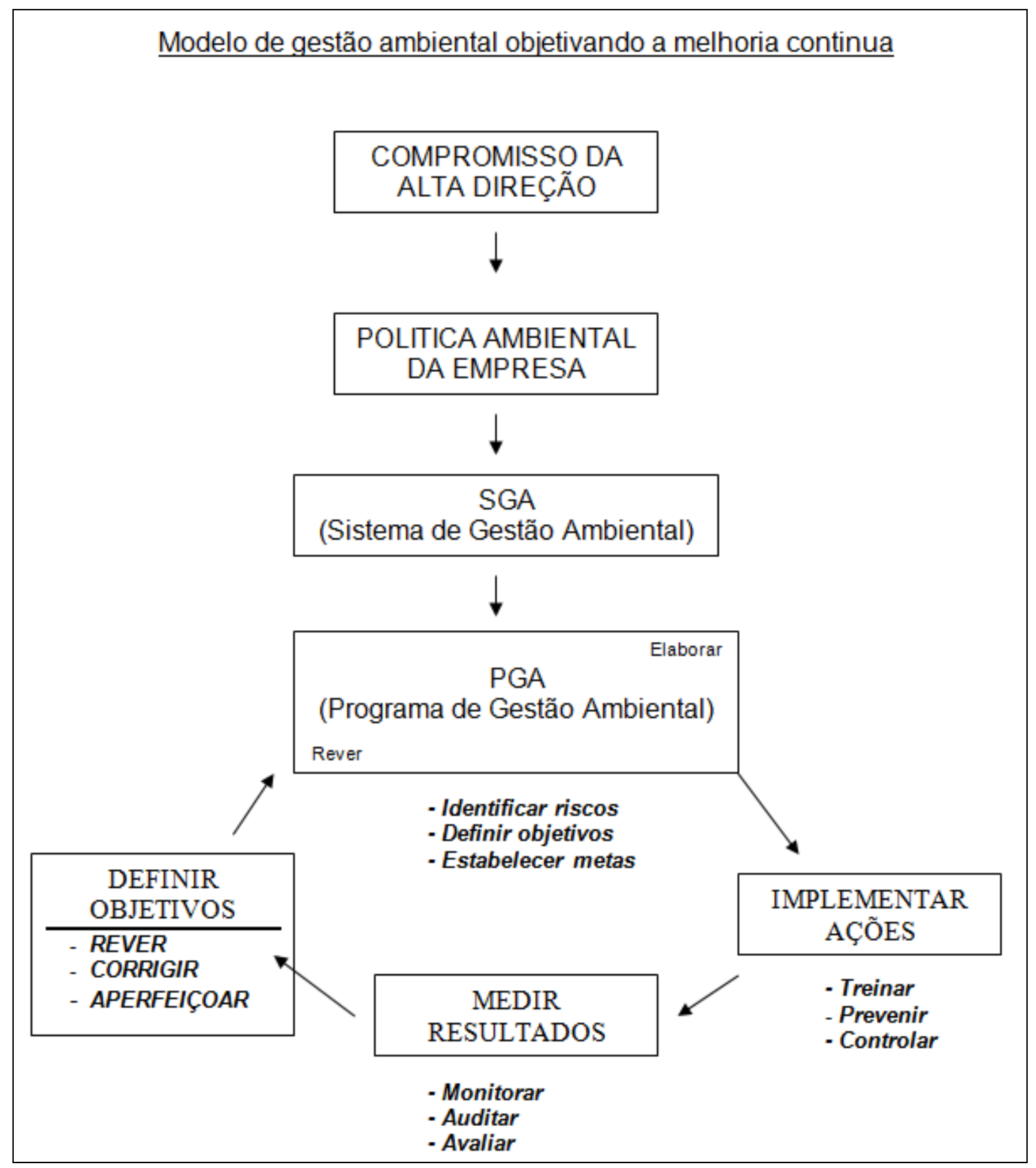

Fluxograma 2: Modelo de gestão ambiental objetivando a melhoria contínua Fonte: VALLE, 2005.

\section{GESTÃO AMBIENTAL COMO VANTAGEM COMPETITIVA}

Ao adotar uma Gestão Ambiental eficiente, a empresa espera assegurar sua sustentabilidade, por meio da implantação de mecanismos e ferramentas adequadas para 
este fim. Para isso, a implantação deve ser levada com muita seriedade e comprometimento de todos na empresa, principalmente da alta administração.

Para se tornar mais competitiva no mercado internacional, a empresa deve desenvolver seu plano de Gestão Ambiental em consonância com os aspectos econômico-contábeis, pois a partir disso serão identificados os custos ambientais gerados pelas atividades e processos organizacionais. Com base nesse diagnóstico financeiro, a organização poderá adotar ações e mecanismos de controle com o intuito de minimizar ou eliminar os custos provenientes do plano ambiental, melhorando decisivamente na eficiência da utilização dos recursos da empresa.

Sobre o aspecto da aplicação de Gestão Ambiental como ferramenta competitiva no mercado, Kraemer (2005) diz:

\begin{abstract}
Assim, pode-se alavancar a estratégia competitiva da empresa e assegurar o cumprimento de seu papel social, através da atuação responsável. Junto às exigências e atribuições de responsabilidade que a sociedade estabelece para as empresas, através de suas leis, são oferecidas oportunidades. A gestão eficiente sabe detectar oportunidades para investimentos rentáveis onde parece haver apenas exigências e despesas.
\end{abstract}

Tendo em vista que no Brasil e no mundo, cada vez mais, difunde-se a preocupação com o meio ambiente, muitas empresas estão optando por adotar Sistema de Gestão Ambiental ou adequação do seu produto às normas ambientais, a fim de que obtenham certificações internacionais. Neste cenário, destaca-se cada vez mais o valor de uma certificação para angariar confiabilidade e competitividade da empresa no mercado internacional. Muitos países desenvolvidos fazem exigências de mercado nesse sentido, relacionadas às certificações ambientais, entretanto os países em desenvolvimento ainda possuem um longo caminho a percorrer, não significando que não seja possível o crescimento econômico da empresa sem a destruição dos recursos naturais.

\title{
CONSIDERAÇÕES FINAIS
}

Tendo em vista que a certificação ambiental é um processo de verificação que determina se organização está atuando conforme os critérios pré-estabelecidos pelas normas técnicas, no caso as normas da série ISO 14000, muitas empresas estão aderindo a um Sistema de Gestão Ambiental em virtude dos seus benefícios e diante das pressões exercidas por uma sociedade mais ecologicamente consciente.

O fator da competitividade não é um evento que advêm dos primórdios, assim sendo, vem em ascensão principalmente na nova ordem econômica atual, visto que representa o potencial de cada empresa em elaborar estratégias competitivas para se sobressair no mercado internacional. Nessa discussão, destacam-se os fatos da modernização do embasamento estratégico, aonde as organizações necessitam fortalecer sua organização interna para que possam sistematizar e dominar um pensamento finalístico, objetivando assim, diferenciar a sua produção em relação ao mercado.

A procura pela competitividade está intrinsecamente relacionada com a concorrência produtiva. Destarte, as empresas devem agregar valor ao que produzem. Entretanto, essa 
proposta de competição não deve se encarada de forma isolada, onde os produtores isolemse em nichos produtivos. Devem analisar de forma minuciosa todo o mercado, para que assim possam captar e perceber o mercado no contexto geral. Nesse contexto, percebemos que a adoção de medidas internas que atendem ao sistema de normalização ambiental em âmbito internacional, agrega um valor diferenciado ao produto - tido como ecologicamente correto- da empresa que se propõe a exportar.

Contudo, os empresários necessitam acima de tudo possuir conhecimento não só das suas empresas, mas sim entender a complexa teia produtiva mundial, encaixando-se nesse contexto através de suas perspectivas produtivas. Para isso deverá traçar objetivos e focálos.

A certificação do ISO 14000 significa adequação dos requisitos e procedimentos presentes em um Sistema de Gestão Ambiental adotado por uma determinada empresa, além de destaque em relação aos concorrentes e melhoria no desempenho ambiental e empresarial. Ao obter essa certificação ambiental, a empresa ganha uma imagem positiva em relação à comunidade, ganhando assim reconhecimento perante todos.

As empresas que possuem a certificação ISO 14000 possuem outros benefícios como o ganho de status e confiabilidade diante do mercado, avançando assim no entrave concorrencial. Existem também aquelas indústrias que almejam essa certificação e a possuem apenas objetivando ascensão no que concerne a questão do "marketing".

No entanto, ainda existem algumas empresas que relutam diante dos benefícios e vantagens de se possuir a certificação da série ISO 14000, baseado na justificativa de que aumentaria os custos da empresa, impossibilitando a obtenção do lucro máximo. Mas essa uma visão bastante retrógrada e fora do contexto estratégico de mercado, na medida em que o mundo converge para uma preocupação natural com o meio ambiental e o mercado está incorporando determinadas exigências de cunho ambiental.

Para tanto, são apresentados alguns motivos fundamentais para que uma empresa adote um Sistema de Gestão Ambiental, entre os quais a redução de custos na organização em função da economia de recursos naturais e diminuição da geração de resíduos, conquista de mercados restritos, economia de recursos pertinentes a processos judiciais, facilidade para obtenção de financiamentos junto a organismos multilaterais de crédito, criação de uma "imagem verde", ganho de status e confiabilidade no mercado internacional.

Por fim, podemos inferir que as certificações ambientais são de suma importância dentro do contexto mercadológico internacional, de maneira que permite as empresas agregar um valor competitivo e sustentável com o meio ambiente.

\section{REFERÊNCIAS}

1. AMARAL, Sérgio Silva. Meio ambiente na agenda internacional: comércio e financiamento. São Paulo, 2005. Disponível em: $<$ http://www.scielo.br/scielo.php?pid=S010340141995000100015\&script=sci_arttext> Acesso em: 02 dez. 2009. Não paginado. 
2. ARMELIN, Marco Antonio. A Consciência ambiental das organizações e sua certificação. São Paulo, 2008. Disponível em < http://adm.cneccapivari.br/?q=node/36> Acesso em: 06 dez. 2009.

3. BARBIERI, José Carlos. Gestão Ambiental Empresarial: Conceitos, Modelos e Instrumentos. São Paulo: Saraiva, 2007.

4. BARRAL, Welber. Medidas antidumping. In: BARRAL, Welber (Org.). O Brasil e a OMC: os interesses brasileiros e as futuras negociações multilaterais. Florianópolis: Diploma legal, 2000. p. 391-410.

5. BIANCHI, Patrícia Nunes Lima. Meio ambiente: certificações ambientais e comércio internacional. Curitiba : Juruá, 2008.

6. CANOTILHO, Joaquim José Gomes. Direito Constitucional e Teoria da Constituição. 7.ed. Coimbra: Almedina, 2003.

7. ORGANIZATION INTERNATIONALE DE NORMALISATION. Apresenta textos sobre normas internacionais de padronização. Disponível em: <http://www.iso.org/iso/fr/home.htm> Acesso em: 5 dez. 2009.

8. CONDURÚ, Marise Teles; PEREIRA, José Almir Rodrigues. Elaboração de trabalhos acadêmicos: Normas, critérios e procedimentos. 2. ed. Belém: UFPA, 2006.

9. CASARA, Ana Cristina. Direito Ambiental do clima e créditos de carbono. Curitiba: Juruá, 2009.

10. CHIAVENATO, I. Introdução á teoria geral da administração: uma visão abrangente da moderna administração das organizações: edição compacta. 3.ed. Rio de Janeiro: Elsevier, 2004.

11. DENARDIN, Valdir Frigo; VINTER, Glaucia. Algumas considerações acerca dos benefícios econômicos, sociais e ambientais advindos da obtenção da certificação iso 14000 pelas empresas. [S.l.: s.n] Disponível em < www.race.nuca.ie.ufrj.br/eco/trabalhos/comu1/4.doc> Acesso em 28 nov. 2009.

12. D`LSEP, Clarissa F.M. Direito Ambiental Econômico e a ISO 14000: Análise jurídica do modelo de gestão ambiental e certificação ISO 14001. São Paulo: Revista dos Tribunais Ltda, 2004.

13. FIORILlO, Celso Antônio Pacheco. Curso de Direito Ambiental Brasileiro. 8.ed. São Paulo: Saraiva, 2007.

14. GHOSHAL, Sumantra; TANURE, Betania. Estratégia e Gestão Empresarial: Construindo empresas brasileiras de sucesso - Estudos de casos. Rio de Janeiro: Elsevier, 2004.

15. GIBERTONI, Carla Adriana Comitre. Teoria e Prática do Direito Marítimo. Rio de Janeiro: Renovar, 2005.

16. GIL, Antonio Carlos. Como elaborar projetos de pesquisa. 4.ed. São Paulo: Atlas, 2002.

17. GRUMMT, Alvaro. Importância da certificação de um SGA-ISO 14001 para as empresas. [S.1.: s.n] Disponível em: 
<http://web03.unicentro.br/especializacao/Revista_Pos/P\%C3\%A1ginas/6\%20Edi\% C3\%A7\%C3\%A3o/Agrarias/PDF/6-Ed6_CA-Impor.pdf> Acesso em: 05 dez. 2009.

18. ISO - International Organization for Standardization. Disponível em < http://www.iso.org/iso/home.htm> Acesso em: 30 nov. 2009.

19. KRAEMER, Maria Elisabeth Pereira. Gestão ambiental: a busca de estratégias para vantagem competitiva e construção da imagem corporativa. [S.1, 2005] Disponível em < http://www.gestiopolis.com/Canales4/ger/buscestrategias.htm $>$ Acesso em: 20 maio 2010.

20. LOCATELLI, Liliana. Proteção ao consumidor e Comércio Internacional. 1.ed. São Paulo: Juruá, 2003.

21. MACHADO, Paulo Affonso Leme. Direito Ambiental Brasileiro. 2.ed. São Paulo: Malheiros, 2005.

22. MAIA, Jayme de Mariz. Economia Internacional e Comércio Exterior. 8.ed. São Paulo: Atlas, 2003.

23. MOREIRA, Maria S. Estratégia e implantação do sistema de gestão ambiental (modelo ISO 14000). Belo Horizonte: Desenvolvimento Gerencial, 2001.

24. NASCIMENTO, Luis Felipe et al. Gestão Socioambiental Estratégica. Porto Alegre: Bookman, 2008.

25. PADOIN, Andréa Inês e Lizandra D et al. Importância do sistema de gestão ambiental na empresa - estudo de caso. Rio de Janeiro, 1998. Disponível em: http://www.abepro.org.br/biblioteca/ENEGEP1998_ART212.pdf. Acesso em $12 \mathrm{de}$ fev.2010.

26. PEGADO, Erika Araújo da Cunha. Impactos da legislação ambiental brasileira na exportação de camarão: um estudo com exportadores de camarão do rio grande do norte. Curitiba, 2007. Disponível em:

<http://engema.up.edu.br/arquivos/engema/pdf/PAP0071.pdf $>$ Acessado em 04 de dez. 2009.

27. PEGADO, Erika Araújo da Cunha. Apostila de Noções de Direito Ambiental. Natal: IFRN, 2009.

28. PIRES, Adilson Rodrigues. Práticas abusivas no comércio internacional. Rio de Janeiro: Forense, 2001.

29. TACHIZAWA, Takeshy e REZENDE, Wilson; Estratégia Empresarial: tendências e desafios - um enfoque na realidade brasileira. São Paulo: Makron Books, 2000.

30. VALLE, Cyro Eyer do. Qualidade ambiental: como ser competitivo protegendo o meio ambiente: (como se preparar para as Normas ISO 14000). São Paulo: Pioneira, 1995.

31. WERKEMA, Maria C. C. Ferramentas estatísticas básicas para o gerenciamento de processos. Belo Horizonte: QFCO,1995. 


\section{ANEXO A}

\section{DECLARAÇÃO DO RIO DE JANEIRO SOBRE MEIO AMBIENTE E DESENVOLVIMENTO HUMANO}

\section{A Conferência das Nações Unidas sobre meio ambiente e desenvolvimento,}

Tendo-se reunido no Rio de Janeiro, de 3 a 14 de junho de 1992,

Reafirmando a Declaração da Conferência das Nações Unidas sobre o Meio Ambiente Humano, adotada em Estocolmo em 16 de junho de 1972, e buscando avançar a partir dela, Com o objetivo de estabelecer uma nova e justa parceria global por meio do estabelecimento de novos níveis de cooperação entre os Estados, os setores-chave da sociedade e os indivíduos,

Trabalhando com vistas à conclusão de acordos internacionais que respeitem os interesses de todos e protejam a integridade do sistema global de meio ambiente e desenvolvimento, Reconhecendo a natureza interdependente e integral da Terra, nosso lar,

\section{Proclama que:}

Princípio 1

Os seres humanos estão no centro das preocupações com o desenvolvimento sustentável. Têm direito a uma vida saudável e produtiva, em harmonia com a natureza.

\section{Princípio 2}

Os Estados, de conformidade com a Carta das Nações Unidas e com os Princípios de Direito Internacional, têm o direito soberano de explorar seus próprios recursos segundo suas próprias políticas de meio ambiente e desenvolvimento, e a responsabilidade de assegurar que atividades sob sua jurisdição ou controle não causem danos ao meio ambiente de outros Estados ou de áreas além dos limites da jurisdição nacional.

Princípio 3

$\mathrm{O}$ direito ao desenvolvimento deve ser exercido de modo a permitir que sejam atendidas equitativamente as necessidades ambientais e de desenvolvimento de gerações presentes e futuras.

\section{Princípio 4}

Para alcançar o desenvolvimento sustentável, a proteção ambiental deve constituir parte integrante do processo de desenvolvimento, e não pode ser considerada isoladamente deste.

\section{Princípio 5}

Todos os Estados e todos os indivíduos, como requisito indispensável para o desenvolvimento sustentável, devem cooperar na tarefa essencial de erradicar a pobreza de forma a reduzir as disparidades nos padrões de vida e melhor atender às necessidades da maioria da população do mundo.

Princípio 6 
A situação e necessidades especiais dos países em desenvolvimento, em particular dos países menos desenvolvidos relativo e daqueles ambientalmente mais vulneráveis, devem receber prioridade especial. Ações internacionais no campo do meio ambiente e do desenvolvimento devem, também, atender aos interesses e necessidades de todos os países. Princípio 7

Os Estados devem cooperar, em um espírito de parceria global, para a conservação, proteção e restauração da saúde e da integridade do ecossistema terrestre. Considerando as distintas contribuições para a degradação ambiental global, os Estados tem responsabilidades comuns, porém diferenciadas. Os países desenvolvidos reconhecem a responsabilidade que tem na busca internacional do desenvolvimento sustentável, $\mathrm{cm}$ vista das pressões exercidas por suas sociedades sobre o meio ambiente global e das tecnologias e recursos financeiros que controlam.

\section{Princípio 8}

Para atingir o desenvolvimento sustentável e mais alta qualidade de vida para todos, os Estados devem reduzir e eliminar padrões insustentáveis de produção e consumo e promover políticas demográficas adequadas.

\section{Princípio 9}

Os Estados devem cooperar com vistas ao fortalecimento da capacitação endógena para o desenvolvimento sustentável, pelo aprimoramento da compreensão científica por meio do intercâmbio de conhecimento científico e tecnológico, e pela intensificação do desenvolvimento, adaptação, difusão, e transferência de tecnologias, inclusive tecnologias novas e inovadoras.

Princípio 10

A melhor maneira de tratar questões ambientais e assegurar a participação, no nível apropriado, de todos os cidadãos interessados. No nível nacional, cada indivíduo deve ter acesso adequado a informações relativas ao meio ambiente de que disponham as autoridades públicas, inclusive informações sobre materiais e atividades perigosas em suas comunidades, bem como a oportunidade de participar de processos de tomada de decisões. Os Estados devem facilitar e estimular a conscientização e a participação pública, colocando a informação à disposição de todos.

Deve ser propiciado acesso efetivo a procedimentos judiciais e administrativos, inclusive no que diz respeito à compensação e reparação de danos.

\section{Princípio 11}

Os Estados devem adotar legislação ambiental eficaz. Padrões ambientais e objetivos c prioridades em matéria de ordenação do meio ambiente devem refletir o contexto ambiental e de desenvolvimento a que se aplicam. Padrões utilizados por alguns países podem resultar inadequados para outros, em especial países em desenvolvimento, acarretando custos sociais e econômicos injustificados.

\section{Princípio 12}

Os Estados devem cooperar para o estabelecimento de um sistema econômico internacional aberto e favorável, propício ao crescimento econômico e ao desenvolvimento sustentável em todos os países, de modo a possibilitar o tratamento mais adequado dos problemas da degradação ambiental. Medidas de política comercial para propósitos 
ambientais não devem constituir-se em meios para a imposição de discriminações arbitrárias ou injustificáveis ou em barreiras disfarçadas ao comércio internacional. Devem ser evitadas ações unilaterais para o tratamento de questões ambientais fora da jurisdição do país importador. Medidas destinadas a tratar de problemas ambientais transfronteiriços ou globais devem, na medida do possível, basear-se em um consenso internacional.

\section{Princípio 13}

Os Estados devem desenvolver legislação nacional relativa à responsabilidade e indenização das vítimas de poluição e outros danos ambientais. Os Estados devem, ainda, cooperar de forma expedita e determinada para o desenvolvimento de normas de direito internacional ambiental relativas à responsabilidade e indenização por efeitos adversos de danos ambientais causados, em áreas fora de sua jurisdição, por atividades dentro de sua jurisdição ou sob seu controle.

Princípio 14

Os Estados devem cooperar de modo efetivo para desestimular ou prevenir a mudança ou transferência para outros Estados de quaisquer atividades ou substâncias que causem degradação ambiental grave ou que sejam prejudiciais à saúde humana.

\section{Princípio 15}

De modo a proteger o meio ambiente, o princípio da precaução deve ser amplamente observado pelos Estados, de acordo com as suas capacidades. Quando houver ameaça de danos sérios ou irreversíveis, a ausência de absoluta certeza científica não deve ser utilizada como razão para postergar medidas eficazes e economicamente viáveis para prevenir a degradação ambiental.

\section{Princípio 16}

Tendo em vista que o poluidor deve, em princípio, arcar com o custo decorrente da poluição, as autoridades nacionais devem promover a internalização dos custos ambientais e o uso de instrumentos econômicos, levando na devida conta o interesse público, sem distorcer o comércio e os investimentos internacionais.

\section{Princípio 17}

A avaliação do impacto ambiental, como instrumento nacional, deve ser empreendida para atividades planejadas que possam vir a ter impacto negativo considerável sobre o meio ambiente, e que dependam de uma decisão de autoridade nacional competente.

\section{Princípio 18}

Os Estados devem notificar imediatamente outros Estados de quaisquer desastres naturais ou outras emergências que possam gerar efeitos nocivos súbitos sobre o meio ambiente destes últimos. Todos os esforços devem ser empreendidos pela comunidade internacional para auxiliar os Estados afetados.

\section{Princípio 19}

Os Estados devem prover oportunamente, a Estados que possam ser afetados, notificação prévia e informações relevantes sobre atividades potencialmente causadoras de considerável impacto transfronteiriço negativo sobre o meio ambiente, e devem consultarse com estes tão logo quanto possível e de boa fé. 
Princípio 20

As mulheres desempenham papel fundamental na gestão do meio ambiente e no desenvolvimento. Sua participação plena e, portanto, essencial para a promoção do desenvolvimento sustentável.

Princípio 21

A criatividade, os ideais e a coragem dos jovens do mundo devem ser mobilizados para forjar uma parceria global com vistas a alcançar o desenvolvimento sustentável e assegurar um futuro melhor para todos.

\section{Princípio 22}

As populações indígenas e suas comunidades, bem como outras comunidades locais, têm papel fundamental na gestão do meio ambiente e no desenvolvimento, em virtude de seus conhecimentos e práticas tradicionais. Os Estados devem reconhecer c apoiar de forma apropriada a identidade, cultura e interesses dessas populações e comunidades, bem como habilitá-las a participar efetivamente da promoção do desenvolvimento sustentável.

\section{Princípio 23}

O meio ambiente e os recursos naturais dos povos submetidos à opressão, dominação e ocupação devem ser protegidos.

\section{Princípio 24}

A guerra é, por sua natureza, contrária ao desenvolvimento sustentável. Os Estados devem, por conseguinte, respeitar o direito internacional aplicável à proteção do meio ambiente em tempos de conflito armado, e cooperar para seu desenvolvimento progressivo, quando necessário.

\section{Princípio 25}

A paz, o desenvolvimento e a proteção ambiental são interdependentes indivisíveis.

\section{Princípio 26}

Os Estados devem solucionar todas as suas controvérsias ambientais de forma pacífica, utilizando-se dos meios apropriados, de conformidade com a Carta das Nações Unidas.

\section{Princípio 27}

Os Estados e os povos devem cooperar de boa fé e imbuídos de um espírito de parceria para a realização dos princípios consubstanciados nesta Declaração, e para o desenvolvimento progressivo; do direito internacional no campo do desenvolvimento sustentável. 


\section{ANEXO B}

\section{CARTA EMPRESARIAL PARA O DESENVOLVIMENTO SUSTENTÁVEL}

A carta de princípios da Câmara de Comércio Internacional - CCI, dirigida às empresas foi publicada em 1991, por ocasião da Segunda Conferência Mundial da Indústria sobre a Gestão do Meio Ambiente. A Carta tem como objetivo comprometer um amplo leque de empresas com a melhoria ambiental, por meio da adoção de programas de gestão ambiental.

$1^{\mathrm{o}}$ - Prioridade na Empresa - Reconhecer a gestão do ambiente como uma das principais prioridades na empresa e como fator dominante do desenvolvimento sustentável; estabelecer políticas, programas e procedimentos para conduzir as atividades de modo ambientalmente seguro.

$2^{\circ}$ - Gestão Integrada - Integrar plenamente em cada empresa essas políticas, programas e procedimentos, como elemento essencial de gestão em todos os seus domínios.

$3^{\circ}$ - Processo de Aperfeiçoamento - Aperfeiçoar continuamente as políticas, os programas e o desempenho ambiental das empresas, levando em conta os desenvolvimentos técnicos, o conhecimento científico, os requisitos dos consumidores e as expectativas da comunidade, tendo como ponto de partida a regulamentação em vigor; e aplicaras mesmos critérios ambientais no plano internacional.

$4^{\circ}$ - Formação do Pessoal - Formar, treinar e motivar o pessoal para desempenhar suas atividades de maneira responsável face ao ambiente.

$5^{\circ}$ - Avaliação Prévia - Avaliar os impactos ambientais antes de iniciar nova atividade ou projeto e antes de desativar uma instalação ou abandonar um local.

$6^{\circ}$ - Produtos e Serviços - Desenvolver e fornecer produtos ou serviços que não produzam impacto indevido sobre o ambiente e sejam seguros em sua utilização prevista, que apresentem o melhor rendimento em termos de consumo de energia e de recursos naturais, que possam ser reciclados, reutilizados ou cuja disposição final não seja perigosa.

$7^{\circ}$ - Conselhos de Consumidores - Aconselhar e, em casos relevantes, propiciar a necessária informação aos consumidores, aos distribuidores e ao público, quanto aos aspectos de segurança a considerar na utilização, transporte, armazenagem e disposição dos produtos fornecidos; e aplicar considerações análogas à prestação de serviços.

$8^{\circ}$ - Instalações e Atividades - Desenvolver, projetar e operar instalações tendo em conta a eficiência no consumo da energia e dos materiais, a utilização sustentável dos recursos renováveis, a minimização dos impactos ambientais adversos e da produção de resíduos e o tratamento ou disposição final desses resíduos de forma segura e responsável

$9^{\circ}$ - Pesquisas - Realizar ou patrocinar pesquisas sobre impactos ambientais das matériasprimas, dos produtos, dos processos, das emissões e dos resíduos associados às atividades da empresa, e sobre os meios de minimizar tais impactos adversos. 
$10^{\circ}$ - Medidas Preventivas - Adequar a fabricação, a comercialização, a utilização de produtos ou serviços, ou a condução de atividades, em harmonia com os conhecimentos científicos e técnicos, para evitar a degradação grave ou irreversível do ambiente.

$11^{\circ}$ - Empreiteiros e Fornecedores - Promover a adoção desses Princípios pelos empreiteiros contratados pela empresa, encorajando e, em casos apropriados, exigindo a melhoria de seus procedimentos de modo compatível com aqueles em vigor na empresa; e encorajar a mais ampla adoção destes Princípios pelos fornecedores.

$12^{\circ}$ - Planos de Emergência - Desenvolver e manter, nos casos em que exista risco significativo, planos de ação para situações de emergência, em coordenação com os serviços especializados, as principais autoridades e a comunidade local, tendo em conta os possíveis impactos transfronteiriços.

$13^{\circ}$ - Transferência de Tecnologias - Contribuir para a transferência de tecnologia e métodos de gestão que respeitem o ambiente, tanto nos setores industriais como nos de administração

pública.

$14^{\circ}$ - Contribuição para o Esforço Comum - Contribuir para o desenvolvimento de políticas públicas, de programas empresariais, governamentais e intergovernamentais, e de iniciativas educacionais que valorizem a consciência e a proteção ambiental.

$15^{\circ}$ - Abertura ao Diálogo - Promover a abertura ao diálogo com o pessoal da empresa e com o público, em antecipação e em resposta às respectivas preocupações quanto ao risco e impactos potenciais das atividades, produtos, resíduos e serviços, incluindo aqueles de significado transfronteiriço ou global.

$16^{\circ}$ - Cumprimento de Regulamentos e Informação - Aferir o desempenho das ações sobre o ambiente, proceder regularmente a auditorias ambientais e avaliar o cumprimento das exigências internas da empresa, dos requisitos legais e destes Princípios; e periodicamente fornecer as informações pertinentes ao Conselho de Administração, aos acionistas, ao pessoal, às autoridades e ao público. 